\title{
Regulation by Threat: Dodd-Frank and the Nonbank Problem
}

\author{
Daniel Schwarcz† and David Zaringt†
}

A central lesson of the global financial crisis is that banks are not the only financial firms that can endanger the broader financial system. The Dodd-Frank Act responded to this reality by empowering a council of financial regulators to designate individual nonbank financial institutions as systemically risky. Although the Financial Stability Oversight Council (FSOC) has exercised this authority only four times, it has occasioned controversy in court, in Congress, and among commentators. And with Donald Trump's 2016 presidential victory, FSOC's designation authority is now in danger of being radically altered or terminated completely. This Article defends the FSOC designation scheme, arguing that its critics misunderstand the mechanisms by which it helps to reduce systemic risk outside the banking sector. FSOC designation does not, and cannot, precisely identify firms that could pose a systemic risk to the financial system. FSOC's broad discretion to impose costly sanctions on designated firms instead advances two quite different goals. First, it deters nonbank firms from seeking out systemically risky strategies or activities. Second, it holds financial regulators to account by threatening to intrude on their regulatory turf if they fail to address systemic risk on their own. We term this approach "regulation by threat" and suggest that it is appropriate when risks are hard to identify, the perils of mistake are great, and the downsides of misdiagnosis extreme. Moreover, we argue that the council's discretion is better cabined by its structurewhich features diverse membership, voting, review, and political safeguards-than by insistence on "hard look" judicial review or a cost-benefit requirement for individual designation decisions. The council offers a useful alternative mechanism to standard approaches to regulation.

I. Understanding the Problem: Nonbank Systemic Risk IN THE Post-

2008 LANDSCAPE

$\dagger$ Professor of Law at the University of Minnesota Law School.

i† Associate Professor at the Wharton School, University of Pennsylvania. Portions of this Article draw on the authors' testimony to Congress and amicus briefs in MetLife, Inc v FSOC. For helpful comments and suggestions, we thank Hilary Allen, Chris Brummer, Peter Conti-Brown, Jeff Gordon, Claire Hill, Bob Hockett, Brett McDonald, Saule Omarova, Richard Painter, Christina Skinner, and Margaret Tahyar, and the audiences at presentations at Cambridge, Oxford, Columbia Business School, the University of Connecticut, the University of Minnesota, Georgetown Law Center, Wharton, and the Indira Gandhi Institute for Development Research. Thanks to Jayme Wiebold for research assistance. 
A. Systemic Risk, Nonbank Financial Firms, and the Financial Crisis.

B. Market Evolution, Regulatory Arbitrage, and the Migration of Systemic Risk.

1. Market change and regulatory arbitrage in the run-up to the crisis...

2. Post-crisis incentives of nonbanks to seek out systemic risk.

II. Dodd-Frank, FSOC DESIGNATION, AND IDENTIFYING SystemiCALly RISKY NONBANK FINANCIAL FIRMS

A. Overview of FSOC's Designation Power

1. Dodd-Frank's designation mechanism. 1835

2. FSOC's final rule and guidance. 1838

3. FSOC's designations to date 1841

B. Key Characteristics of Nonbank SIFIs and the Residual Uncertainty in Identifying These Firms. 1843

III. REgUlation BY THREAT: THE LOGIC OF FSOC's REGULATORY ARCHITECTURE

A. FSOC Designation and Firm-Level Deterrence

1. The deterrent force of designation.

2. Firm-level deterrence and the reduction of systemic risk 1855

B. FSOC Designation and the Adaptation of Primary Financial Regulations.

IV. The Legitimacy of Regulation By Threat. 1864

A. The Legitimacy of Regulation by Threat in Financial Supervision, and Elsewhere

B. The Substantive Constraints on the Council's Authority

C. The Procedural Curbs on the Council's Discretion 1871

D. Implications for Policy 1876

CONCLUSION 1880

\section{INTRODUCTION}

The global financial crisis was much more than a disaster for banks. In fact, some of the worst parts of the crisis-the surprising collapse of the country's largest insurance company on the same day that one of its oldest money market funds collapsed, and one day after two of its largest investment banks fell, for example-_id not involve banks at all. ${ }^{1}$

1 On September 15, 2008, two investment banks were closed-Merrill Lynch was sold at a cut-rate price, and Lehman Brothers went bankrupt. See generally Andrew Ross Sorkin, Lehman Files for Bankruptcy; Merrill Is Sold (NY Times, Sept 14, 2008), archived at http://perma.cc/7HUB-4UYA. One day later, the insurance giant AIG accepted an $\$ 85$ billion bailout that gave the federal government a 79.9 percent stake in the company, and the Reserve Primary Fund, a large and trendsetting money market fund, "broke[] the 
The government responded to this nonbank problem by creating the Financial Stability Oversight Council (FSOC, or the "council")-a panel of the nation's most prominent financial regulators with the power to designate particular financial firms as systemically significant. Designated firms are subject to various specific anti-insolvency rules-including minimum capital and liquidity requirements-and supervision by the Federal Reserve (the "Fed"). ${ }^{2}$

This power of the council, although it has been utilized only four times, has occasioned considerable controversy in court, in Congress, and among commentators. ${ }^{3}$ The chair of the Senate Banking Committee has wondered whether the council's designation decisions are "sufficiently open, objective, data driven, and free from the influence of outside organizations." 4 The Republican Party's presidential platforms in both 2012 and 2016 have committed the party to revoking the council's powers. ${ }^{5}$ One court has

buck." See In re The Reserve Fund Securities and Derivative Litigation, 673 F Supp 2d 182, 198 (SDNY 2009). For a discussion, see generally Jill E. Fisch, The Broken Buck Stops Here: Embracing Sponsor Support in Money Market Fund Reform, 93 NC L Rev 935 (2015). At the close of the second day, the Dow Jones Industrial Average had fallen 800 points since the start of the week. Brenna Maloney and Todd Lindeman, Five Days That Transformed Wall Street: Sept. 15-19, 2008 (Wash Post, Sept 20, 2008), archived at http://perma.cc/E3UJ-GQUZ. See also Jerome L. Stein, Stochastic Optimal Control and the U.S. Financial Debt Crisis 111 (Springer 2012) (suggesting that the government's decision to rescue the insurance company, AIG, was driven in part by the collapse of the money market fund, Reserve Primary).

212 USC \$5323(a)(1) (providing that FSOC "may determine that a US nonbank financial company shall be supervised by the Board of Governors and shall be subject to prudential standards").

3 See, for example, Peter J. Wallison, The Latest Twist in a Regulatory Sham (Wall St J, Sept 10, 2014), online at http://www.wsj.com/articles/peter-j-wallison-the-latest -twist-in-a-regulatory-sham-1410389724 (visited May 17, 2017) (Perma archive unavailable) ('Jeb Hensarling (R., Texas) has also called on FSOC to 'cease and desist' further designations .... The House backed Mr. Hensarling in July by passing an appropriationsbill amendment that imposed a one-year moratorium on SIFI designations.").

4 Senate Committee on Banking, Housing, and Urban Affairs, Shelby Statement at Hearing on FSOC Accountability (Mar 25, 2015), archived at http://perma.cc/KX4W $-\mathrm{N} 6 \mathrm{QH}$.

5 See Republican Platform: Restoring the American Dream (GOP, 2016), archived at http://perma.cc/GE6E-6U49 (calling for the repeal of the "regulatory nightmare" of the Dodd-Frank Wall Street Reform Act and replacement with "legislation to ensure that the problems of any financial institution can be resolved through the Bankruptcy Code"); 2012 Republican Party Platform: We Believe in America (American Presidency Project, Aug 27, 2012), archived at http://perma.cc/2YTB-TJMX ("A Republican Congress and President will repeal the [Dodd-Frank Act] ...."). 
reversed the council's designation of the country's largest life insurer as an arbitrary and capricious exercise of its authority. ${ }^{6}$ And many commentators speculate that President Donald Trump may formally or informally terminate or radically alter FSOC's designation process. ${ }^{7}$ Indeed, an executive order has already been promulgated that changes the focus of the council, 8 and the first comprehensive postelection reform proposal to the Dodd-Frank Act ${ }^{9}$ - the Financial CHOICE Act-would completely eliminate FSOC's designation power. ${ }^{10}$

These critics typically assume that the core purpose of FSOC designation is to accurately and consistently identify nonbank financial firms whose collapse would threaten the financial system. ${ }^{11}$ They often imply that FSOC can accomplish this only by developing a detailed and analytically complete account of what factors render a nonbank financial firm systemically suspect, complete with a quantified and comprehensive cost-benefit analysis conducted in the course of any particular designation. ${ }^{12}$

The council's designation decisions look less like the critics' preferred sort of precise determination and more like an inference, based on a range of factors and evidence, that material financial distress at targeted firms "could" contribute to broader financial instability. This approach, they suggest, could plausibly permit "any nonbank financial company [to] meet the standard of

6 See Metlife, Inc v Financial Stability Oversight Council, 177 F Supp 3d 219, 241 (DDC 2016) (applying a controversial cost-benefit requirement to reverse the designation), citing Michigan v Environmental Protection Agency, 135 S Ct 2699, 2707 (2015).

7 See, for example, Ryan Tracy, How a Financial Council Republicans Loathe Could Work in Their Favor (Wall St J, Jan 17, 2017), online at http://www.wsj.com/articles/ how-a-financial-council-republicans-loath-could-work-in-their-favor-1484581368 (visited Aug 21, 2017) (Perma archive unavailable) (discussing how to "maintain FSOC's authority-and use it for different aims").

8 See Executive Order $13772 \S 2$ (2017), 82 Fed Reg 9965, 9965 ("The Secretary of the Treasury shall consult with the heads of the member agencies of the Financial Stability Oversight Council and shall report to the President" on a broad array of policy goals, including "advanc[ing] American interests in international financial regulatory negotiations and meetings" and "foster[ing] economic growth and vibrant financial markets through more rigorous regulatory impact analysis that addresses systemic risk and mar. ket failures, such as moral hazard and information asymmetry.").

9 Dodd-Frank Wall Street Reform and Consumer Protection Act, Pub L No 111-203, 124 Stat 1376 (2010).

10 See generally House Financial Services Committee, The Financial CHOICE Act: Executive Summary (Feb 28, 2017), archived at http://perma.cc/8QGA-KLY4.

11 See, for example, Republican Staff of the House Financial Services Committee, The Arbitrary and Inconsistent FSOC Nonbank Designation Process *4 (2017), archived at http://perma.cc/S8PN.KNZE.

12 See Metlife, $177 \mathrm{~F}$ Supp 3d at 239-40 (requiring the council to conduct a quantified cost-benefit analysis of designation before designating any particular firm). 
a threat."13 FSOC applies its broad-ranging and flexibly defined authority, critics conclude, to arbitrarily and inconsistently designate a subset of disfavored firms. ${ }^{14}$

We defend the way the council regulates in this Article. The council was created not to adjudicate between safe and risky businesses as a court might, or to create a mathematical formula that firms can apply to their balance sheets to see if they are risky. Instead, it was created to encourage all financial firms to avoid taking excessive risks. ${ }^{15}$ It has chosen to do this by taking action against some, and in so doing, warning the rest. The threat of FSOC designation-and the regime of enhanced regulatory requirements and supervision by the Fed that comes along with itis meant to deter nonbank financial firms from seeking out risk. It is also designed to hold nonbanks' primary financial regulators to account. When firms that they oversee face insufficient systemic risk regulation, FSOC threatens to intrude on their regulatory turf.

We call this scheme "regulation by threat." Regulation by threat requires that a regulator will have the broad discretion to impose costly sanctions on those they regulate; done well, it will be a power the regulator wields rarely. The use of regulatory threats can, in the right circumstances and with the right constraints, induce caution in an industry inclined to risky behavior that is difficult to police.

The council's regulatory powers fit this scheme well. It is capable of making effective threats that have a real deterrent effect precisely because of the discretion that it enjoys in applying a malleable standard to identify systemically important financial institutions (SIFIs). Nonbank financial firms facing a risk of being deemed systemically significant by FSOC will tend to avoid embracing strategies that could create systemic risks because designation comes along with costly regulatory restrictions and supervision. By contrast, nonbanks that know that the council will not designate them if they abide by pre-specified rules might

1.3 FSOC Nonbank Designation Process at *5 (cited in note 11).

14 Id at *3.

15 See Financial Stability Oversight Council (FSOC), archived at http://perma.cc/V4VE-T2GK ("The Council is charged with identifying risks to the financial stability of the United States; promoting market discipline; and responding to emerging risks to the stability of the United States' financial system."). 
take on risk to increase their odds of outsized gains, with, potentially, the promise of a bailout if things go wrong and the attendant low cost of capital that accompanies this prospect.

Regulation by threat works only if designation is costly. ${ }^{16}$ The evidence so far suggests that the council's threats are working: both industry and regulators have changed their conduct to avoid costly council oversight. FSOC recently rescinded its designation of GE Capital as systemically significant after the firm sold off its operations related to short-term debt markets, which were a focus of FSOC's initial designation decision. ${ }^{17}$ And investors or management in two of the three other designated firms-American International Group (AIG) and MetLife-have urged their firms to pursue a similar strategy, an invitation that AIG accepted. ${ }^{18}$ After, among other things, exiting business in ways that made that company less interconnected with the rest of the financial system and reducing "the amounts of its total debt outstanding, short-term debt, derivatives, securities lending, repurchase agreements, and total assets, in some cases significantly," as FSOC put it, it also won de-designation. ${ }^{19}$ Indeed, the entire insurance industry has taken steps to lessen the prospect of designation by the council, a process that already appears to be bearing fruit with AIG. ${ }^{20}$ Moreover, regulators have worried about losing turf to the Fed-the threat they face if they fail to properly supervise risky nonbanks. Here too, recent evidence-including a series of Securities and Exchange Commission (SEC) rulemakings geared toward financial stability in the money markets and emerging reforms in state insurance regulation-is illustrative. ${ }^{21}$

All of this can be characterized as standards-based regulation, in which the requirements for designation of nonbanks are

16 See Louis Kaplow and Steven Shavell, Fairness versus Welfare, 114 Harv L Rev 961,1226 (2001) (observing that law enforcement often pursues "the reduction in the commission of harmful acts through the threat of sanctions").

17 See Financial Stability Oversight Council, Basis for the Financial Stability Oversight Council's Rescission of Its Determination regarding GE Capital Global Holdings, $L L C{ }^{*}$ 9-10 (June 28, 2016), archived at http://perma.cc/NWD8-3MYK.

18 See text accompanying notes $210,217$.

19 See Financial Stability Oversight Council, Notice and Explanation of the Basis for the Financial Stability Oversight Council's Rescission of Its Determination regarding American International Group, Inc. (AIG) ${ }^{{ }^{*} 6}$ (Sept 29, 2017), archived at http://perma.cc/F6F2-SCXH.

20 See Part III.A.

21 See note 246 and accompanying text. 
kept broad and subject to interpretation..$^{22}$ But FSOC's regime of regulation by threat is not just an example of regulation by standard. It is, as a matter of law, unique. We do not ordinarily associate the broad discretion to administer intensive oversight, sometimes on recipients surprised to be subjected to the treatment, with good government. As a first approximation, that power to surprise and penalize sounds like arbitrariness. Moreover, scholars have grumbled that permitting regulators to use threats of enforcement reduces their incentives to regulate through noticeand-comment rulemaking, which in turn permits them to evade judicial review. ${ }^{23}$ This risk has led even scholars willing to live with threat-based regulation, such as Professor Tim Wu, to conclude that it is only "under certain circumstances[] a superior means of regulatory oversight." 24

We conclude that the judicious deployment of regulation by threat is both appropriate and necessary in the context of regulating systemic risk outside of the banking sector. ${ }^{25}$ Threats, deterrence, and the strict supervision of some are appropriate when the risks are hard to identify, the perils of mistake are great, and the downsides of misdiagnosis are extreme. These are characteristics of a mission to prevent financial crises outside of the banking sector, and they exist regardless of the technological ferment. ${ }^{26}$ The use of enforcement threats also can be an efficient use

22 The dynamics of standards-based regulation have produced a voluminous literature across the firmament of legal disciplines. See, for example, Thomas W. Merrill, The Mead Doctrine: Rules and Standards, Meta-Rules and Meta-Standards, 54 Admin L Rev 807, 819-26 (2002) (looking at rules- and standards-based approaches to judicial review of agency action); Gideon Parchomovsky and Alex Stein, Catalogs, 115 Colum L Rev 165, 208-09 (2015) (outlining the rules-and-standards debate and highlighting some of the leading scholarly participants in it).

23 See, for example, Jerry Brito, "Agency Threats" and the Rule of Law: An Offer You Can't Refuse, 37 Harv J L \& Pub Pol 553, 562 n 47, 564-65 (2014); Philip Hamburger, Is Administrative Law Unlawful? 260-61 (Chicago 2014) (worrying about the breadth of agency enforcement powers). See also Appalachian Power Co v Environmental Protection Agency, 208 F3d 1015, 1020 (DC Cir 2000) (describing how agencies evade judicial review by refusing to issue narrowing regulations and thereby retaining discretion to act as they choose in particular cases).

24 Tim Wu, Agency Threats, 60 Duke L J 1841, 1848 (2011). "Threat regimes . . a are best justified when the industry is undergoing rapid change - under conditions of high uncertainty." Id at 1842 .

25 We also tie the threat to final agency action, reviewable by a court-the designation of a nonbank financial institution as systemically significant-unlike $\mathrm{Wu}$, who would apply it to "warning letters, official speeches, interpretations, and private meetings with regulated parties." Id at 1844.

26 See, for example, Steven L. Schwarcz, Regulating Complexity in Financial Markets, 87 Wash U L Rev 211, 223-27 (2009) (noting the immense downside of financial crises); Hilary J. Allen, A New Philosophy for Financial Stability Regulation, 45 Loyola U 
of regulatory resources. The council has quite rigorously overseen a substantial segment of the financial system by selecting four firms for particular attention. ${ }^{27}$

More generally, regulation by threat might be one effective way to regulate when a precautionary principle is appropriate, the threat of regulation can deter risky behavior, and precisely defining risky behavior ex ante is impossible. ${ }^{28}$ As Professor Cass Sunstein has explained, two tests for evaluating when regulators should take a "better safe than sorry" approach are (1) when "regulators lack information about the likelihood and magnitude of a risk," and so "buy an 'option' to protect against irreversible harm until future knowledge emerges"; and (2) when "risks have extremely bad worst-case scenarios." ${ }^{29}$ These criteria do not just apply to nonbank systemic risk regulation. Many scholars have called for more oversight of enforcement decisions at agencies ranging from the Department of Justice to the SEC. ${ }^{30}$ They worry that regulators choose enforcement because they do not have to justify any particular prosecution through the hurdles of Administrative Procedure Act ${ }^{31}$ (APA) rulemaking procedure..$^{32}$ Regulators can and should act through notice and comment when doing so is likely to effectively defuse the underlying risks. ${ }^{33}$ But

Chi L. J 173, 195-97 (2013) (arguing for the use of the precautionary principle in financial regulation).

27 Designations (FSOC, Jan 31, 2017), archived at http://perma.cc/2FFB-UV9F (not ing the designation of AIG, General Electric Capital Cooperation, Prudential Financial, and MetLife as firms for particular attention).

28 See Cass R. Sunstein, Laws of Fear: Beyond the Precautionary Principle 109-28 (Cambridge 2005). The precautionary principle originated in continental legal systems and appears in the Treaty of the European Communities (EC) in Article 174. Jan Bohanes, Risk Regulation in WTO Law: A Procedure-Based Approach to the Precautionary Principle, 40 Colum J Transnatl L 323, 331 n 24 (2002).

29 Cass R. Sunstein, Irreversible and Catastrophic, 91 Cornell L Rev 841, 84546 (2006).

30 Some scholars have worried that the breadth of enforcement discretion in administrative law is worryingly uncabined. See, for example, Rachel E. Barkow, Overseeing Agency Enforcement, 84 Geo Wash L Rev 1129, 1137 (2016) ("Throughout the federal system, agencies often use enforcement and adjudication (as opposed to rulemaking) to set norms, and there is reason to worry that agencies may misuse their discretion."). Others have argued that aspects of agencies like the SEC in civil enforcement actions also ought to be subject to more procedural constraints. See, for example, David Zaring, Enforcement Discretion at the SEC, 94 Tex L Rev 1155, 1158-59 (2016) (listing critics and observing that "agencies have always enjoyed unfettered discretion to choose their enforcement targets").

3160 Stat 237 (1946), codified as amended in various sections of Title 5.

32 See Barkow, 84 Geo Wash L Rev at 1160 (cited in note 30).

33 See National Petroleum Refiners Association v Federal Trade Commission, 482 F2d 672, 681 (DC Cir 1973) ("[C]ourts are recognizing that use of rule-making to make 
when it is difficult to tell in advance what conduct will create risks, regulators must be permitted to regulate through enforcement and example-making; it is a form of regulation that has a venerable pedigree in, for example, policing tax evasion and antitrust violations. ${ }^{34}$ In financial regulation itself, the designation of financial institutions as complicit in the financing of terrorism or the activities of enemy states involves a similar designation process and a similar sort of example-making. ${ }^{35}$

The broader implications of regulation by threat, however, do not distract us from a second aspect of the central question this Article answers-whether the council's designation process is legal. That aspect requires a consideration of the checks on the council's power, given that some of the conventional constraints of administrative law-reducing discretion through ex ante rulemaking and requiring a cost-benefit analysis-are inappropriate for the council's mission.

We argue that the council's discretion is better cabined by its structure than by insistence on particularly "hard look" judicial review or cost-benefit analysis for any individual designation decision. ${ }^{36}$ Although the council's procedures look like a rather unorthodox form of administrative law, they feature voting, review, and political safeguards, all of which support the case for the legitimacy of the way the council does designations. ${ }^{37}$

First, and perhaps most importantly, FSOC is a council, not an agency, and designation requires a series of affirmative votes by supermajorities of the council's membership. This membership incorporates a number of diverse viewpoints and, unlike other interagency committees, uniquely includes voices of state regulators in its mix. As a council with no independent regulatory turf of its own, it is immune from the regulatory temptation to grow its own programs. 38

innovations in agency policy may actually be fairer to regulated parties than total reliance on case-by-case adjudication.").

34 See notes 267-68 and accompanying text.

35 See David Zaring and Elena Baylis, Sending the Bureaucracy to War, 92 Iowa L Rev 1359, 1397-99 (2007) (describing the Treasury Department's Office of Foreign Assets Control designation process).

36 But see Metlife, $177 \mathrm{~F}$ Supp 3d at 241 (reversing the council's designation of MetLife on "hard look" review and requiring the council to conduct a cost-benefit analysis). Obviously, we disagree with the court's analysis.

37 About FSOC (FSOC, Feb 27, 2017), archived at http://perma.cc/VY37-X2HU.

38 See, for example, Jonathan R. Macey and Geoffrey P. Miller, Reflections on Professional Responsibility in a Regulatory State, 63 Geo Wash L Rev 1105, 1119 (1993) (describing the turf-building problem). 
Second, although FSOC's substantive standard for designating nonbanks as systemically important is indeed flexible, it was itself adopted through a process of notice-and-comment rulemaking and, partially as a result, includes a number of guideposts and safe harbors that limit FSOC's discretion. For instance, FSOC's final rule on designation both identifies the factors on which the council will focus in making designation determinations and presumptively excludes from designation firms with less than $\$ 50$ billion in total consolidated assets. These standards limit or eliminate the threat of designation for the vast majority of nonbanks.

Third, the parallel processes of SIFI designation by international organizations like the Financial Stability Board (FSB) provide an underappreciated check on FSOC's exercise of its power. ${ }^{39}$ Increasingly, financial regulators have made themselves, with congressional approval and the president's support, part of an international web of regulation, meant to respond to the fact that capital easily crosses borders, and that these days financial institutions do as well. ${ }^{40}$ FSOC is not the only institution in this global environment that designates financial institution as systemically risky; this also limits its discretion. ${ }^{41}$

Our analysis not only offers the benefit of making sense of the unorthodox regulatory remit of a powerful, new federal entity. It also answers many of the specific challenges to designation leveled by FSOC's critics and helps resolve policy questions that have arisen as FSOC has done its business. For instance, it suggests that FSOC should retain its relatively unfettered hand to designate nonbank financial institutions if it is to fulfill its purpose. This requires rejecting calls from critics to require FSOC to engage in more detailed cost-benefit analysis, a requirement that risks imposing an impossible burden on the council and thus neutering its capacity to deter the aggregation of systemic risk.

None of this is to suggest that FSOC's designation process is beyond reproach, and we could see it usefully being reformed in ways that would remove a degree of potential politicization among its decision-makers and expand the diversity of viewpoints

39 See David Zaring, Finding Legal Principle in Global Financial Regulation, 52 Va $J$ Intl L 683, 700-01 (2012) (describing how the FSB makes decisions).

40 See Jean Galbraith and David Zaring, Soft Law as Foreign Relations Law, 99 Cornell L Rev 735, 746 (2014) (describing this evolution).

41 See, for example, id at 746,761-62 (detailing the existence of the International Organization of Securities Commissions and the FSB in this regulatory space). 
available to it. ${ }^{42}$ But these improvements would affect the structure of the council; its processes, we think, are entitled to respect. More generally, regulation by threat is not held up here as some sort of regulatory perfection. Instead, such regulation is the best of the alternatives, when less supervision would lead to industry risk-taking and more precise regulation would likely be misguided.

In what follows, Part I outlines the persistent, but difficultto-detect and ever-changing, tendency of nonbank financial firms to take on systemic risk. In Part II, we describe FSOC's designation process and the inherent difficulties associated with any judgments about which firms could and could not prove systemically significant in the midst of a future crisis. In Part III, we explain how FSOC's designation process operates as a dual threat against individual nonbank firms that might seek out systemic risk and their primary regulators who might allow this to occur on their watch. Finally, Part IV suggests that regulation by threat is a legitimate approach to regulating systemic risk more generally, as well as in the council's case.

\section{UNDERSTANDING THE PROBLEM: NONBANK SYSTEMIC RISK IN THE POST-2008 LANDSCAPE}

Financial regulation classically divided financial institutions into three categories: banks, insurers, and securities firms. Within this tripartite framework, only banking regulation was seriously concerned about financial stability. ${ }^{43}$ By contrast, both securities and insurance regulation focused on goals like protecting investors and policyholders, and promoting robust capital and insurance markets. ${ }^{44}$ Although fissures in this conventional framework emerged in the 1990 s and early 2000 s, the financial crisis shattered the notion that nonbank firms do not pose systemic risks. Part I.A explains how this came to be, describing the wide range of nonbank financial firms that played central roles in the crisis, including investment banks, mutual funds, and insuranceoriented financial conglomerates. Recapitulating these problems both provides a factual basis for understanding why Congress

42 See Part IV.

43 The relationship between systemic risk and banking regulation has been appreciated for well over a century. See, for example, Walter Bagehot, Lombard Street: A Description of the Money Market 298-300 (C. Kegan Paul \& Co 7th ed 1878).

44 See generally Zohar Goshen and Gideon Parchomovsky, The Essential Role of Securities Regulation, 55 Duke L J 711 (2006). 
gave the council a mandate to take on systemic risk in the nonbank sector and suggests how difficult it is to predict where risk in that sector will originate.

Part I.B then shows how the migration of systemic risk to nonbank institutions was largely a product of individual firms actively seeking to exploit the pre-crisis fragmented regulatory scheme. Even more importantly, Part I.B explains how policymakers' management of the financial crisis increased nonbank firms' incentives to engage in regulatory arbitrage that can produce systemic risk, at least in the absence of regulatory reforms like those contained in Dodd-Frank (discussion of which is postponed until Part II). By confirming that government actors will rescue nonbank firms whose failures could have significant spillover effects on the broader financial system, the 2008 bailouts increased the incentives facing nonbank firms to seek out systemic risk in order to decrease their cost of capital.

\section{A. Systemic Risk, Nonbank Financial Firms, and the Financial Crisis}

Prior to 2008, financial regulation was largely premised on the assumption that banks are fundamentally different from other types of financial institutions. ${ }^{45}$ According to this narrative, banks play a central role in the economy but are also uniquely susceptible to the risk of failure because depositors can withdraw funds on demand, creating the prospect of self-reinforcing bank runs. ${ }^{46}$ By contrast, nonbank financial institutions-such as insurance companies, investment banks, and pooled-investment companies like hedge funds and mutual funds-were conventionally thought to pose only limited risks to the broader financial system or macroeconomy. ${ }^{47}$ Perhaps most fundamentally, this

45 See, for example, E. Gerald Corrigan, Are Banks Special? (Federal Reserve Bank of Minneapolis, Jan 1982), archived at http://perma.cc/8X7L-PH9Y; E. Gerald Corrigan, Are Banks Special? A Revisitation *1 (Federal Reserve Bank of Minneapolis, Mar 1, 2000), archived at http://perma.cc/4JQS-2G4J; Daniel R. Fischel, Andrew M. Rosenfield, and Robert S. Stillman, The Regulation of Banks and Bank Holding Companies, $73 \mathrm{Va}$ L Rev 301, 306-07 (1987). For a recent historical account of how banks came to be separated from other types of financial institutions in the Glass-Steagall Act, see generally Arthur E. Wilmarth Jr, Prelude to Glass-Steagall: Abusive Securities Practices by National City Bank and Chase National Bank during the "Roaring Twenties", 90 Tulane L Rev 1285 (2016).

46 See Richard Scott Carnell, Geoffrey P. Miller, and Jonathan R. Macey, The Law of Financial Institutions 49-60 (Aspen 5th ed 2013).

47 See Christina Parajon Skinner, Regulating Nonbanks: A Plan for SIFI Lite, 105 Georgetown L J 1379, 1388-89 (2017). 
was because none of these institutions funded themselves with demand deposits. ${ }^{48}$

This conventional distinction between banks and nonbank financial institutions undergirded the pre-2008 regime of financial regulation. Banks, of course, were heavily regulated because of their fundamental role in the financial system and broader macroeconomy. But the regulation of nonbank financial entities was predominantly focused on concerns other than financial stability, such as protecting consumers or investors, or promoting capital formation or robust insurance markets. ${ }^{49}$

Although strains in this narrative started emerging in at least the $1990 \mathrm{~s},{ }^{50}$ it was not until after the financial crisis-the most significant financial crisis in nearly a century-that it became obvious that nonbank financial firms could indeed pose large systemic risks. Many of the most important institutions to fail or be bailed out in the financial crisis-including Bear Stearns, Lehman Brothers, AIG, the Reserve Primary Fund, and Fannie Mae-were not commercial banks at all.51 Instead, they were nonbank financial institutions, such as investment banks, insurance companies, mutual funds, and government-sponsored enterprises (GSEs), operating in mortgage markets. ${ }^{52}$

The nonbank financial firms that were most directly implicated in the financial crisis were the five "bulge bracket" investment banks, none of which currently exists in its pre-crisis form..$^{53}$

48 See id at 1387 n 26.

49 See Daniel Schwarcz and Steven L. Schwarcz, Regulating Systemic Risk in Insurance, 81 U Chi L Rev 1569, 1579-84 (2014) (describing how insurance regulation was not traditionally concerned with systemic risk); Donald C. Langevoort, Selling Hope, Selling Risk: Corporations, Wall Street, and the Dilemmas of Investor Protection 140-41 (Oxford 2016) (noting that the SEC has traditionally not focused on regulating for the purpose of limiting systemic risk).

50 See Franklin R. Edwards, Hedge Funds and the Collapse of Long-Term Capital Management, $13 \mathrm{~J}$ Econ Persp 189, 192-93 (Spring 1999) (detailing the attrition rate of hedge funds in response to the collapse of the Russian economy in the 1990s).

51 To be sure, a number of commercial banks, such as Wachovia, Washington Mutual, and IndyMac, did fail during the crisis, and the impact of the crisis on commercial banks was a first-order concern in the midst of the crisis. See Adam J. Levitin, Book Review, The Politics of Financial Regulation and the Regulation of Financial Politics: A Review Essay, 127 Harv L Rev 1991, 2054-55 (2014).

52 See Skinner, 105 Georgetown L J at 1387-89 \& nn 24, 26 (cited in note 47) (noting that shadow banking played a key role in the crisis and that many of the investment banks that were part of this system were not regulated like traditional banks).

53 Two of these firms (Bear Stearns and Merrill Lynch) were purchased by commer. cial banks, one (Lehman Brothers) failed, and two (Goldman Sachs and Morgan Stanley) 
These firms contributed to the crisis in at least two ways: by producing the mortgage-backed securities that propagated throughout the broader financial system and by failing or nearly failing during the midst of the crisis. ${ }^{54}$ Several common factors caused the failures or near-failures of these large investment banks. ${ }^{65}$ First, most of these institutions relied substantially on short-term borrowing markets, particularly repo markets, to finance their operations..$^{56}$ In much the same way that depositors can run on a traditional bank by pulling their funds, lenders in these markets effectively "ran" on the large investment banks by collectively refusing to roll over their short-term debt. ${ }^{57}$ Second, all of these investment banks operated with extraordinarily high amounts of leverage. ${ }^{88} \mathrm{As}$ a result, they faced enhanced incentives to seek out risk and a decreased capacity to absorb losses. ${ }^{59}$ Third, each of these institutions was substantially invested in securitized bonds that were ultimately linked to the health of the US real estate market. ${ }^{60}$

More surprising than the troubles these five investment megabanks faced during the crisis were the evident systemic implications of these firms' potential failures. This proposition was put to the test but once, when federal actors allowed Lehman Brothers to fail rather than bailing out the firm. This precipitated unanticipated panic throughout the financial system and is often viewed as the most dramatic accelerant of panic during the entire

converted to bank holding companies. See Steven M. Davidoff and David Zaring, Regulation by Deal: The Government's Response to the Financial Crisis, 61 Admin L Rev 463, 491-94 (2009).

54 On the former point, see Senate Permanent Subcommittee on Investigations, Wall Street and the Financial Crisis: Anatomy of a Financial Collapse *11 (Apr 13, 2011) ("Levin-Coburn Report"), archived at http://perma.cc/Z268-KBC3 ("Investment banks were the driving force behind the structured finance products that provided a steady stream of funding for lenders originating high risk, poor quality loans and that magnified risk throughout the U.S. financial system.").

55 See generally Onnig H. Dombalagian, Requiem for the Bulge Bracket?: Revisiting Investment Bank Regulation, 85 Ind L J 777 (2010).

56 See generally Gary Gorton and Andrew Metrick, Securitized Banking and the Run on Repo, 104 J Fin Econ 425 (2012).

57 See Kathryn Judge, The First Year: The Role of a Modern Lender of Last Resort, 116 Colum L Rev 843, 854-55 (2016).

58 Financial Crisis Inquiry Commission, The Financial Crisis Inquiry Report: Final Report of the National Commission on the Causes of the Financial and Economic Crisis in the United States *xix (Jan 2011), archived at http://perma.cc/D2CF-SS5W (noting that in 2007, the five major investment banks were operating with "extraordinarily thin capital").

69 See generally Anat Admati and Martin Hellwig, The Bankers' New Clothes: What's Wrong with Banking and What to Do about It (Princeton 2013).

60 See Gorton and Metrick, $104 \mathrm{~J}$ Fin Econ at 430 (cited in note 56). 
crisis period. ${ }^{61}$ In large part, these investment banks' systemic significance stemmed from their interconnections with the broader financial system. For instance, investment banks' primary counterparties included many of the largest commercial banks, meaning that their failure could have jeopardized the conventional banking system. ${ }^{62}$ At the same time, the systemic significance of the five largest investment banks was also no doubt related to the inchoate perceptions and fears of individual actors within the financial markets, a consideration that obviously cannot be easily explained or quantified.

Many other central players in the crisis were neither commercial banks nor investment banks, but instead entirely different types of financial entities. AIG, for instance, was a financial services holding company that primarily engaged in the business of insurance. ${ }^{33}$ The company's near-failure in 2008 was primarily attributable to two activities at the firm. The first involved the sale of credit default swaps (CDS)—which essentially "insured" the risk faced by other major financial institutions that their mortgage-related securities would default-by the company's Financial Products division. ${ }^{64}$ These CDS obligated AIG to post ever more collateral as payment default on the underlying securities became more likely and AIG's own financial health became more precarious. The second cause of AIG's near-failure was the company's ill-fated securities-lending program, whereby it lent out the assets of its insurers to a variety of large financial institutions in exchange for cash collateral, which it then invested in real estate-backed securities..$^{65}$ These securities-lending contracts were very short term, thus allowing spooked counterparties to refuse to roll over the loans and demand a return of their cash collateral. Fatally to AIG, the risks associated with its securitieslending and CDS programs were highly correlated, resulting in the company facing crises in these two settings at exactly the

61 See generally Ben S. Bernanke, The Courage to Act: A Memoir of a Crisis and Its Aftermath (Norton 2015). See also The Financial Crisis Inquiry Report at *xix (cited in note 58).

62 See James Bullard, Christopher J. Neely, and David C. Wheelock, Systemic Risk and the Financial Crisis: A Primer, 91 Fed Reserve Bank St Louis Rev 403, 407-08 (2009).

63 See William K. Sjostrom Jr, The AIG Bailout, 66 Wash \& Lee L Rev 943, 94546 (2009).

64 See id at $947-51$.

65 See Hester Peirce, Securities Lending and the Untold Story in the Collapse of AIG *18, 27 (Mercatus Center, George Mason University, Working Paper No 14-12, May 2014), archived at http://perma.cc/6M6R-XAVL. 
same time. ${ }^{66}$ But once again, the most surprising element of AIG's sudden failure was that it threatened to promote contagion across the financial system, principally by exposing the company's CDS and securities-lending counterparties to unknown and unanticipated losses. ${ }^{67}$

Another nonbank that played a central role in the unfolding of the financial crisis was the Reserve Primary Fund. As with all money market mutual funds, the Reserve Primary Fund sought to maintain a stable net asset value of $\$ 1$ by investing in shortterm low-risk debt and using amortized cost accounting. ${ }^{68}$ But as a result of Lehman's failure, the Reserve Primary Fund-which had invested about 1 percent of its holdings in Lehman's commercial paper-"broke the buck," meaning that it was forced to disclose that the value of its assets had fallen below one dollar per share. ${ }^{69}$ Investors that had previously perceived these funds to be absolutely safe panicked, swiftly seeking to redeem their shares. Reserve Primary's assets plunged more than 60 percent in two days. ${ }^{70}$ Over the course of that week, panic spread to other money market mutual funds, with investors withdrawing over $\$ 170$ billion. ${ }^{71}$ This had real consequences for the broader economy; money market funds hoarded cash and stopped investing in large US corporations' commercial paper, thus undermining these firms' ability to finance their working capital at a time when credit on that scale was largely unavailable. ${ }^{72}$ The run on money market funds and cessation of their investments in short-term debt ended only after the Treasury and Fed announced the Temporary Guarantee Program for Money Market Funds. ${ }^{73}$

66 See Daniel Schwarcz, A Critical Take on Group Regulation of Insurers in the United States, 5 UC Irvine L Rev 537, 553-54 (2015).

67 See generally Robert McDonald and Anna Paulson, AIG in Hindsight, $29 \mathrm{~J}$ Econ Persp 81 (Spring 2015).

68 See William A. Birdthistle, Breaking Bucks in Money Market Funds, 2010 Wis L Rev 1155, 1175.

69 Id at $1161-62$.

70 See Davidoff and Zaring, 61 Admin L Rev at 505 (cited in note 53). Evergreen Investments, a money market fund owned by Wachovia, for example, had to be bailed out by its parent to avoid breaking the buck. See Daisy Maxey, Sponsors to Back Some Lehman Exposure (Wall St J, Sept 17, 2008), online at http://www.wsj.com/ articles/SB122161204181845907 (visited Aug 22, 2017) (Perma archive unavailable).

71 See Diana B. Henriques, Treasury to Guarantee Money Market Funds (NY Times, Sept 19, 2008), online at http://www.nytimes.com/2008/09/20/business/ 20moneys.html?mcubz=1 (visited Aug 22, 2017) (Perma archive unavailable).

72 See The Financial Crisis Inquiry Report at *31-34 (cited in note 58).

73 See 17 CFR $\S \S 270,274$. 
Yet another set of nonbanks that played a vital role in the financial crisis were the GSEs Fannie Mae and Freddy Mac. ${ }^{74}$ In the run up to the crisis, these GSEs began purchasing increasingly risky loans and becoming ever more leveraged, following a similar trajectory to investment banks like Lehman Brothers and Bear Stearns. ${ }^{75}$ And like these entities, the GSEs suffered everincreasing losses on their portfolio of mortgage-backed securities throughout late 2007 and 2008 , until they experienced their own liquidity shortfall because of their inability to borrow in the wholesale funding markets. ${ }^{76}$ By September 2008, policymakers were forced to place the GSEs in receivership and inject hundreds of billions of dollars into them. ${ }^{77}$ Failing to do so, most agree, would have substantially exacerbated the crisis: without the GSEs continuing to promote lending in the housing market, that market would have further deteriorated, producing losses both for ordinary homeowners and the rest of the financial sector that had invested so heavily in real estate-linked securities. ${ }^{78}$

The list of nonbank financial institutions that were centrally involved in the financial crisis could continue for some time. It would undoubtedly include some nonbank mortgage originators, such as Countrywide Financial, which were responsible for originating the loans that ultimately formed the basis of the toxic real estate assets that spread throughout the financial system. ${ }^{79} \mathrm{It}$ might well also include entities like the monoline financial guarantee insurers, whose troubles quite directly led to the seizing up of the $\$ 330$ billion market for auction-rate securities that were relied on by municipalities, museums, schools, and similar entities. ${ }^{80}$ And it would also likely include certain finance companies like GE Capital, which relied heavily on short-term funding that evaporated in the crisis and provided an important source of credit for ordinary consumers and household goods. ${ }^{81}$ But the

74 See The Financial Crisis Inquiry Report at *19 (cited in note 58).

75 Id at $* 292,310$.

76 Id at *309-11.

77 See generally Steven Davidoff Solomon and David Zaring, After the Deal: Fannie, Freddie, and the Financial Crisis Aftermath, 95 BU L Rev 371 (2015) (discussing the collapse of Fannie Mae and Freddie Mac); Adam B. Badawi and Anthony J. Casey, The Fannie and Freddie Bailouts through the Corporate Lens, 10 NYU J L \& Bus 443 (2014).

78 Solomon and Zaring, 95 BU L Rev at 380-84 (cited in note 77).

79 See Kathleen C. Engel and Patricia A. McCoy, The Subprime Virus: Reckless Credit, Regulatory Failure, and Next Steps 149-52 (Oxford 2011) (discussing the role of nonbank mortgage originators like Countrywide in causing the 2008 crisis).

80 See Schwarcz and Schwarcz, 81 U Chi L Rev at 1586-87 (cited in note 49).

81 See Rescission of GE Determination at *2 (cited in note 17). 
point should now be clear: not only can nonbank financial institutions pose systemic risks to the broader financial system, but they in fact played a central role in causing the most devastating financial crisis in this country since the Great Depression.

\section{B. Market Evolution, Regulatory Arbitrage, and the Migration of Systemic Risk}

The traditional notion that systemic risk is confined to the commercial banking sector worked well enough for about seventy years. Yet the prominent role of nonbanks in the financial crisis was no fluke. Instead, it was the result of constant change in the underlying financial system, with nonbank firms engaging in new activities, offering new products, and adopting new strategies. In many cases, these innovations were specifically designed to exploit unappreciated, or underappreciated, gaps in the tripartite regulatory regime that presumed systemic risk was relevant only to bank regulation. ${ }^{22}$ Part I.B.1 briefly explains the primacy of regulatory arbitrage among nonbanks in causing the 2008 crisis. Part I.B.2 then emphasizes the familiar point that regulators' interventions during the crisis increased the incentives of nonbank financial firms to seek out systemic risk and thereby benefit from an implicit government backstop.

1. Market change and regulatory arbitrage in the run-up to the crisis.

Regulatory arbitrage consists of firms taking advantage of gaps between the riskiness of a practice and the regulatory treatment of that practice. ${ }^{83}$ Because regulatory efforts to reduce risk generally impose costs on firms, such as compliance expenses or activity restrictions, firms may seek out these regulatory gaps. ${ }^{84}$

Regulatory arbitrage's role in causing systemic risk to migrate to nonbank institutions is easiest to appreciate with respect

82 Of course, regulatory arbitrage is a long-standing dynamic in a broad variety of financial regulatory settings. See Dan Awrey, Complexity, Innovation, and the Regulation of Modern Financial Markets, 2 Harv Bus L Rev 235, 256 n 104, 265 (2012). For a treatment of regulatory arbitrage, see generally Victor Fleischer, Regulatory Arbitrage, 89 Tex L Rev 227 (2011).

83 See Fleischer, 89 Tex L Rev at 229 (cited in note 82 ).

84 They may not always do so, of course. Risk-averse firms may prefer to stay within the confines of risk-reducing regulation. See Miriam Hechler Baer, Governing Corporate Compliance, 50 BC L Rev 949, 997 (2009) ("[A] risk-averse compliance officer might be quite happy to implement a highly effective compliance program."). 
to money market mutual funds. ${ }^{85}$ These funds originated out of a combination of high inflation in the 1970 s and regulatory rules capping the interest rate that banks could pay on deposits. Money market mutual funds endeavored to avoid these regulatory restrictions while functionally operating like bank accounts. To do so, they lobbied the SEC to adopt accounting rules that would allow them to maintain a net asset value of $\$ 1$ and to allow shareholders to write checks on the funds. In exchange, they agreed to invest in short-term, high-quality, liquid securities, such as commercial paper. ${ }^{86}$ As described above, the result of these innovations was that investors could and did run en masse from these funds until the government created an ex post federal guarantee program analogous to Federal Deposit Insurance Corporation (FDIC) insurance. ${ }^{87}$

The risks posed by the largest investment banks were also a result of dramatic changes in these firms' business models and the markets in which they operated. Investment banks were traditionally relatively conservative institutions, in part because they were organized as partnerships. ${ }^{88}$ But as investment banks shed this status and became publicly owned companies, they increasingly sought out greater sources of risk that could enhance their bottom line in the short term. ${ }^{89}$ The evolution of securitization and repo markets starting in the mid-1980s helped investment banks accomplish this objective by allowing them to fund their operations with large amounts of relatively cheap credit. ${ }^{90}$ The fact that this credit consisted of short-term loans that creditors could refuse to roll over at a moment's notice was largely overlooked by securities regulators, who assumed that these firms' own risk-management incentives were sufficient. Meanwhile, the firms themselves presumed that, in anything but the most dire circumstances, they could secure alternative financing, albeit at a higher cost-a straightforward misunderstanding of the financial environment. And to the extent that they even considered scenarios when such high-cost financing would not be

85 See Birdthistle, 2010 Wis L Rev at 1157 (cited in note 68).

86 See id. See also 17 CFR §§ $270,274$.

87 See text accompanying note 57 .

88 See Claire A. Hill and Richard W. Painter, Better Bankers, Better Banks: Promoting Good Business through Contractual Commitment 95-99 (Chicago 2015).

89 See id at 71-80, 100-07.

90 See Gorton and Metrick, $104 \mathrm{~J}$ Fin Econ at 432 (cited in note 56). 
available, they likely assumed either that the government would assist them or that they would be out of a job in any event. ${ }^{91}$

AIG's dramatic near-failure was also a product of the company exploiting regulatory blind spots to seek out short-term profit. ${ }^{22}$ For instance, AIG's CDS operations entirely avoided state insurance regulation because they were conducted from a foreign, noninsurance entity-AIG Financial Products. ${ }^{93}$ Meanwhile, even though AIG's securities-lending operations directly implicated the securities owned by its insurance companies, AIG avoided serious regulatory scrutiny of these operations by coordinating them through several noninsurance affiliates of the company. ${ }^{94}$ This resulted in no individual insurance regulator taking primary responsibility for carefully scrutinizing that program or appreciating that AIG Financial Products subjected AIG to risk that was highly correlated with the firm's CDS activities. ${ }^{95}$

Although regulatory arbitrage was therefore a key ingredient in the increase in firms' systemic risk levels leading up to the crisis, plenty of nonbanks appear to have simply misapprehended the riskiness of what they were doing. For instance, Fannie Mae and Freddie Mac, with a wealth of experience in housing finance, were utterly unprepared for the collapse of the mortgage market. Similarly, Reserve Primary may have been investing in unsecured Lehman Brothers debt because it was chasing yield and loading up on risk, or it may have done so because it failed to understand how the short-term debt markets worked, or both.

91 See Hill and Painter, Better Bankers, Better Banks at 3-10 (cited in note 88).

92 Although the US Office of Thrift Supervision (OTS) technically supervised AIG Financial Products, the office's pre-crisis regulatory oversight is generally understood to have been woefully deficient, in part because regulated firms had the option to shop for the OTS as their regulator. See, for example, The Levin-Coburn Report at *208-39 (cited in note 54). This was particularly true with respect to nonbanking products, for which the agency lacked expertise. See Financial Crisis Inquiry Commission, Statement by Ben $S$. Bernanke, Chairman, Board of Governors of the Federal Reserve System * 13 (Sept 2, 2010), archived at http://perma.cc/9MSK-K9H2 (noting that the OTS's supervision of AIG's derivatives activities in its financial-products unit "was extremely limited in practice").

93 See Schwarcz and Schwarcz, $81 \mathrm{U}$ Chi L Rev at 1584-87 (cited in note 49).

94 See id; US Government Accountability Office, Financial Crisis: Review of Federal Reserve System Financial Assistance to American International Group, Inc. *13 (Sept 2011), archived at http://perma.cc/W938-TGUY ("Prior to mid-2007, state regulators had not identified losses in the securities lending program, and the lead life insurance regulator had reviewed the program without major concerns.").

95 See Schwarcz, 5 UC Irvine L Rev at 553 (cited in note 66). 
2. Post-crisis incentives of nonbanks to seek out systemic risk.

The financial crisis thus demonstrated not only that nonbanks can be systemically risky but also that the precise ways in which this can occur are constantly shifting as a result of regulatory arbitrage and broader market trends. At the same time, policymakers' willingness to bail out nonbanks in the midst of the crisis increased the incentives of nonbank financial firms to become systemically risky so as to benefit from this implicit government backstop. Throughout the financial crisis, government actors repeatedly bailed out nonbank financial firms and industries when they perceived that doing otherwise would cause the crisis to spread further. ${ }^{96}$ Although these bailouts remain immensely unpopular among the general population, a majority of policymakers and experts agree that they ultimately helped prevent a much worse financial crisis that would have plunged the United States into a much deeper and more sustained recession. ${ }^{97}$

Holding the applicable regulatory regime constant, these facts tend to incentivize nonbank financial firms to become systemically significant so that they can enjoy the benefits of an implicit government guarantee..$^{98}$ By becoming systemically riskyor being perceived to be systemically risky by financial marketsa firm can now, in the post-crisis era, increase the perceived chances that it will be bailed out if it comes close to failure during a broader period of financial instability. This, in turn, can decrease the costs to that firm of funding its operations, as creditors accept lower rates of return in exchange for a perceived implicit government guarantee that the debtor firm will not be allowed to fail in a subset of situations. Indeed, numerous studies demonstrate this effect, documenting that large financial

96 See Adam J. Levitin, In Defense of Bailouts, 99 Georgetown L J 435, 437-38 (2011) (recounting the "spectacular parade" of bailouts during the financial crisis from 2007 to 2009).

97 See, for example, Timothy F. Geithner, Stress Test: Reflections on Financial Crises 502-05 (Crown 2014); Bernanke, The Courage to Act at 366-67 (cited in note 61).

98 See John C. Coffee Jr, Systemic Risk after Dodd-Frank: Contingent Capital and the Need for Regulatory Strategies beyond Oversight, 111 Colum L Rev 795, 800 (2011) (arguing that some firms specifically sought out risk prior to the crisis so that they would be considered too big to fail); John C. Coffee Jr, The Political Economy of Dodd-Frank: Why Financial Reform Tends to Be Frustrated and Systemic Risk Perpetuated, 97 Cornell L Rev 1019,1050 (2012). It is impossible to document this effect in the post-crisis world precisely because regulation has not been held constant: the Dodd-Frank Act created a host of reforms designed to deter individual firms from becoming systemically significant. FSOC's capacity to designate nonbanks as systemically significant is just one of those reforms. 
firms enjoy lower borrowing costs than implied by their risk because of investor expectations of government support in tail-end situations. ${ }^{99}$

\section{DODD-FRANK, FSOC DESIGNATION, AND IDENTIFYING SYSTEMICALLY RISKY NONBANK FINANCLAL FIRMS}

Dodd-Frank adopts several different approaches to responding to the risk that a nonbank financial firm might become systemically risky. For instance, it establishes new rules for riskcreating activities that apply regardless of the types of institutions engaging in those activities. ${ }^{100}$ It also creates a new resolution regime for any nonbank financial firm whose failure would have systemic consequences. ${ }^{101}$ However, Dodd-Frank's most direct approach to addressing the risks described in Part I is to empower the council to determine which specific nonbanks pose a systemic threat. ${ }^{102}$ Firms that are so designated are subject to enhanced prudential standards and supervision by the Fed.

Part II.A outlines this designation regime. It describes FSOC's relatively malleable standard for identifying nonbank SIFIs, which incorporates a broad range of relevant quantitative and qualitative factors rather than a precise rule-like definition. At the same time, this standard provides a presumptive safe harbor from designation for the vast majority of nonbank firms that do not surpass specific, quantitative thresholds.

Using the FSOC regime as a jumping-off point, Part II.B then explores the key characteristics of nonbank SIFIs, as well as the residual uncertainty that currently exists about how best to identify these firms. In doing so, Part II.B emphasizes an inherent difficulty of FSOC designation: the distinction between nonbank firms that are systemically significant and those that are not is

99 See, for example, Viral V. Acharya, Deniz Anginer, and A. Joseph Warburton, The End of Market Discipline? Investor Expectations of Implicit Government Guarantees *35 (working paper, May 1, 2016), archived at http://perma.cc/74D3.VBX4; US Government Accountability Office, Large Bank Holding Companies: Expectations of Government Support *1 (July 2014), archived at http://perma.cc/WEW3-RPSG; Joao Santos, Evidence from the Bond Market on Banks' "Too-Big-to-Fail" Subsidy, 20 Fed Reserve Bank NY Econ Pol Rev 29, 33-34 (Dec 2014).

100 See generally Kristin N. Johnson, Clearinghouse Governance: Moving beyond Cosmetic Reform, 77 Brooklyn L Rev 681 (2012).

101 See David A. Skeel Jr, Single Point of Entry and the Bankruptcy Alternative, in Martin Neil Baily and John B. Taylor, eds, Across the Great Divide: New Perspectives on the Financial Crisis 311, 317-19 (Hoover 2014).

102 Hilary J. Allen, Putting the "Financial Stability" in Financial Stability Oversight Council, 76 Ohio St L J 1087, 1116-18 (2015). 
inherently murky. Although broad consensus exists on many of the relevant factors for assessing whether an individual nonbank firm is systemically significant, it is impossible to predict with any modicum of certainty how any single firm's financial distress or range of activities might reverberate throughout the broader financial system in some hypothetical, future, financially stressed world.

\section{A. Overview of FSOC's Designation Power}

FSOC designation is a product of both Dodd-Frank's statutory text and the council's final rule that implemented these provisions. Part II.A.1 describes the statutory framework, while Part II.A.2 elaborates on FSOC's implementation. Finally, Part II.A.3 discusses FSOC's designations to date.

1. Dodd-Frank's designation mechanism.

Dodd-Frank grants FSOC expansive authority to collect and analyze information relating to systemic risk and to recommend regulatory or legislative reforms to Congress, federal and state agencies, and the public more generally. ${ }^{103}$ For instance, FSOC enjoys a broad range of data-gathering and data-analysis tools, the most important of which is its authority to provide direction to, and request data from, the Office of Financial Research (OFR), an independent bureau within the Treasury Department. ${ }^{104}$ Similarly, FSOC must annually report and testify to Congress on a host of issues, including regulatory developments and its recommendations for improving financial stability. ${ }^{105}$

However, FSOC's primary substantive power is its authority to designate nonbank financial companies as "systemically important" (a term widely used in practice that does not, amusingly enough, appear in the statute itself). ${ }^{106}$ By contrast, FSOC cannot

103 See Dodd-Frank Act $\S \S 112-20,124$ Stat at 1394-1410, 12 USC $\S \S 5322-30$.

104 Dodd-Frank Act $\S 112(\mathrm{a})(2), 124$ Stat at 1395-96, 12 USC $\S 5322(\mathrm{a})(2)$. The OFR, in turn, has the authority to require nonbank financial companies to submit data or periodic reports to the office, so long as that data is not available directly from the firm's primary financial regulator. See Dodd-Frank Act $\S 112(d)(3), 124$ Stat at 1397, 12 USC $\S 5322(\mathrm{~d})(3)$.

105 See Dodd-Frank Act $\S 112(\mathrm{a})(2), 124$ Stat at 1395-96, 12 USC $\S 5322(\mathrm{a})(2)$.

106 See Dodd-Frank Act $\S 113,124$ Stat at 1398-1402, 12 USC $\S 5323$. See also Stavros Gadinis, From Independence to Politics in Financial Regulation, $101 \mathrm{Cal} \mathrm{L}$ Rev 327, 369 (2013). FSOC also has the authority to "identify systemically important financial market utilities and payment, clearing, and settlement activities," a power that it has exercised. Dodd-Frank Act $\S 112(\mathrm{a})(2)(\mathrm{J}), 124$ Stat at 1395, 12 USC $\S 5322(\mathrm{a})(2)(\mathrm{J})$. 
set supervisory priorities for member agencies or develop new or revised regulations regarding activities or practices that are under their jurisdiction. Instead, FSOC simply has persuasive authority with respect to these key elements of the financial regulatory universe. For instance, FSOC can "recommend[]" that member agencies apply "new or heightened standards and safeguards for financial activities or practices that could" generate systemic risk. ${ }^{107}$ But member agencies need not accept these recommendations, so long as they provide an explanation for their decision. ${ }^{108}$

Exercising this designation requires an affirmative vote of at least seven of FSOC's ten voting members, including its chairperson, the secretary of the treasury. ${ }^{109}$ When the council exercises this power, it must explain the basis for its determination to the firm and the public. ${ }^{110}$

Firms that are designated as systemically important by the council are subject to enhanced prudential standards and supervision by the Fed."11 Dodd-Frank specifies that these prudential standards must be "more stringent" than those applicable to firms that do not present similar risks to financial stability. ${ }^{112}$ It also mandates that they include requirements relating to risk-based capital, liquidity, risk management, resolution planning, singlecounterparty credit limits, and stress tests. ${ }^{113}$ However, DoddFrank grants the Fed broad discretion to craft these rules based on the specific risk profiles of designated firms, a fact that Congress clarified in post-Dodd-Frank legislation. ${ }^{114}$ The Fed has recently started implementing this authority for systemically risky nonbank firms predominantly engaged in the business of insurance, issuing an Advanced Notice of Proposed Rulemaking that

107 Dodd-Frank Act $\S 112(\mathrm{a})(2)(\mathrm{K}), 124$ Stat at 1395,12 USC $\S 5322(\mathrm{a})(2)(\mathrm{K})$.

108 See Dodd-Frank Act $\$ 120$ (c)(2), 124 Stat at 1409, 12 USC $\S 5330(\mathrm{c})(2)$.

109 Dodd-Frank Act $\S 113(\mathrm{a})(1), 124$ Stat at 1398,12 USC $\S 5323(\mathrm{a})(1)$.

110 See Dodd-Frank Act $\$ 113(\mathrm{e})(1),(3), 124$ Stat at 1401, 12 USC $\S 5323(\mathrm{e})(1),(3)$

111 Dodd-Frank Act $\S 165,124$ Stat at 1423-32, 12 USC $\S 5365$.

112 Dodd-Frank Act $\$ 115(a)(1)(A), 124$ Stat at 1403, 12 USC $\$ 5325(a)(1)(A)$.

113 Dodd-Frank Act $\S 165(\mathrm{~b})(1)(\mathrm{A}), 124$ Stat at 1424, 12 USC $\S 5365(\mathrm{~b})(1)(\mathrm{A})$. The Fed is also authorized to adopt a broad range of additional prudential standards, such as contingent-capital and enhanced disclosure requirements. Dodd-Frank Act $\S 165(b)(1)(B), 124$ Stat at 1424, 12 USC $§ 5365(b)(1)(B)$.

114 See Insurance Capital Standards Clarification Act of $2014 \S 202$, Pub L No 113 . 279,128 Stat 3017,3018 , codified at 12 USC $\$ 5371$ (c). 
would establish specific capital and liquidity requirements for these companies. ${ }^{115}$

This designation process is, in many ways, less intrusive than the way that systemically significant banks are regulated. Those institutions, if they have more than $\$ 50$ billion in assets, are presumed to be designated, meaning that more banks are subject to additional supervision by the Fed than are nonbanks, which require individualized determinations rather than the application of asset (or other) thresholds. ${ }^{116}$

Congress constrained FSOC's authority to designate firms as systemically significant in several ways. First, it required FSOC to designate firms under one of two standards: FSOC must find that the firm "could pose a threat to the financial stability of the United States" either (i) in the event of its "material financial distress"; or (ii) due to "the nature, scope, size, scale, concentration, interconnectedness, or mix of [its] activities." 117 Second, it enumerated ten different factors that FSOC shall consider in deciding whether a firm meets one of these two designation standards. ${ }^{118}$ Third, it limited designation to firms "predominantly

115 See generally Board of Governors of the Federal Reserve System, Capital Requirements for Supervised Institutions Significantly Engaged in Insurance Activities, 81 Fed Reg 38631 (2016).

116 Dodd-Frank Act $\S 121,124$ Stat at 1410-11, 12 USC $\S 5331$.

117 Dodd-Frank Act $\S 113(\mathrm{a})(1), 124$ Stat at 1398, 12 USC $\S 5323(\mathrm{a})(1)$. In each of its four designations, FSOC has chosen to focus on the first designation standard, which analyzes on the potential impact of "material financial distress" at the company. Dodd-Frank Act $\S 113(\mathrm{a})(1), 124$ Stat at 1398,12 USC $\$ 5323(\mathrm{a})(1)$. In his dissent to the MetLife decision, Roy Woodall, the independent member with insurance expertise on FSOC, criticized the council for ignoring the second designation standard. See Financial Stability Oversight Council, Views of the Council's Independent Member Having Insurance Expertise *1 (Dec 18, 2014), archived at http://perma.cc/99HP-NUAS.

118 Dodd-Frank Act $\S 113,124$ Stat at 1398-1402, 12 USC $\S 5323$. The financial activities are:

(A) the extent of the leverage of the company; (B) the extent and nature of the off-balance-sheet exposures of the company; (C) the extent and nature of the transactions and relationships of the company with other significant nonbank financial companies and significant bank holding companies; (D) the importance of the company as a source of credit for households, businesses, and State and local governments and as a source of liquidity for the United States financial system; (E) the importance of the company as a source of credit for low-income, minority, or underserved communities, and the impact that the failure of such company would have on the availability of credit in such communities; (F) the extent to which assets are managed rather than owned by the company, and the extent to which ownership of assets under management is diffuse; (G) the nature, scope, size, scale, concentration, interconnectedness, and mix of the activities of the company; $(\mathrm{H})$ the degree to which the company is already regulated by 1 or more primary financial regulatory agencies; (I) the amount and nature 
engaged in financial activities," 119 thus exempting the Apples and Walmarts of the economy from fears of supervision by the Fed. Additionally, it provided that designated firms are to be subject to annual reviews to determine whether the designation is still appropriate. ${ }^{120}$

\section{FSOC's final rule and guidance.}

Congress required FSOC to consider a broad range of factors in deciding which nonbank firms could pose "a threat to the financial stability of the United States."121 FSOC's final implementing rule, adopted under standard notice and comment procedures, ${ }^{122}$ simplified this structure in some ways and elaborated on it in others. Perhaps even more importantly, it established a three-stage process for the council to exercise this authority.

With respect to the substantive standard for designation, FSOC's final rule and guidance reorganized Dodd-Frank's ten statutory factors into six broad categories: (1) size; (2) substitutability; (3) interconnectedness; (4) leverage; (5) liquidity risk and maturity mismatch; and (6) existing regulatory scrutiny. ${ }^{123}$ The first three of these categories "seek to assess the potential impact

of the financial assets of the company; [and] (J) the amount and types of the liabilities of the company, including the degree of reliance on short-term funding.

Dodd-Frank Act $\S 113(\mathrm{a})(2), 124$ Stat at 1398, 12 USC $\S 5323(\mathrm{a})(2)$. The list of considerations concludes with a catchall provision: "any other risk-related factors that the Council deems appropriate." Dodd-Frank Act $\S 113(\mathrm{a})(2)(\mathrm{K}), 124$ Stat at 1398,12 USC $\S 5323(\mathrm{a})(2)(\mathrm{K})$.

119 Dodd-Frank Act $\S \S 102(a)(4)(B)(i i),(a)(6), 113,124$ Stat at 1391-92, 1398-1402, 12 USC $\S \S 5311(\mathrm{a})(4)(\mathrm{B})(\mathrm{ii}),(\mathrm{a})(6), 5323$. Such firms must derive 85 percent or more of their consolidated annual gross revenues from financial activities, or have 85 percent or more of their assets related to activities that are "financial in nature." Dodd-Frank Act $\S 102(\mathrm{a})(6), 124$ Stat at 1392,12 USC $\S 5311(\mathrm{a})(6)$

120 Dodd-Frank Act $\S 113(d), 124$ Stat at 1401, 12 USC $\S 5323(d)$.

121 Nonbank Designations-FAQ (FSOC, Feb 4, 2015), archived at http://perma.cc/G2KD-8TJR.

122 See id:

Before adopting its rule and interpretive guidance on nonbank financial company designations, the FSOC voluntarily solicited public comment three times over an 18-month period. This notice and comment process benefited from input from companies and trade organizations representing a broad array of financial sectors, as well as academics and public interest groups.

123 Financial Stability Oversight Council, Authority to Require Supervision and Regulation of Certain Nonbank Financial Companies, 77 Fed Reg 21637, 21658-60 (2012), amending 12 CFR Part 1310. FSOC's implementing rule further defined a threat to the financial stability of the United States to exist if "there would be an impairment of financial intermediation or of financial market functioning that would be sufficiently severe to inflict significant damage on the broader economy." Id at 21657. 
of the nonbank financial company's financial distress on the broader economy." 124 The second three "seek to assess the vulnerability of a nonbank financial company to financial distress," 225 an inquiry that "shed[s] light on the effects that distress could have on the company, and on how the company may respond in the event of material financial distress." 126 According to FSOC, its use of the word "vulnerability" to describe the final three categories does not require it to conduct an independent assessment of designated firms' likelihood of failure. ${ }^{127}$ In addition to these six categories, FSOC's guidance suggests a seventh relevant factor not directly contained in Dodd-Frank: the complexity and resolvability of the financial institution. ${ }^{128}$ Above all, the council indicated it would look to see if the firm would, if it ran into trouble, "inflict significant damage on the broader economy" by disrupting the financial system. ${ }^{129}$

FSOC's final rule also described the ways that a firm's activities or material financial distress could spread throughout the financial system, which it describes as three "transmission channels." ${ }^{130}$ Under the exposure channel, a firm's creditors, counterparties, investors, or other market participants could directly suffer losses due to the firm's losses. ${ }^{131}$ Second, under the asset liquidation channel, a nonbank financial company that quickly liquidated its assets could thereby "disrupt trading or funding in key markets or cause significant losses or funding problems for other firms with similar holdings." ${ }^{132}$ Finally, a firm's activities or financial distress could reverberate throughout the larger financial system if that firm supplied a critical function or service to financial markets. ${ }^{133}$

In addition to clarifying the substantive standard for designation, the council also established a three-stage procedure by which it planned to implement this standard. ${ }^{34}$ Stage 1 of that process operates as a quantitative screening mechanism to

124 Id at 21658.

125 Id.

126 Brief for Appellant, MetLife v Financial Stability Oversight Council, Civil Action

No 16-5086, ${ }^{\star} 29$ (DC Cir filed June 16, 2016) (available on Westlaw at 2016 WL 3356866).

127 Id at ${ }^{\star} 28$.

12877 Fed Reg at 21646 (cited in note 123).

129 Id at 21657.

130 Id.

131 Id.

13277 Fed Reg at 21657 (cited in note 123).

133 Id.

134 Id at 21641-47. 
identify, based on publicly available data, an initial set of nonbanks that might be systemically important. For purposes of Stage 1, FSOC defined the following six "uniform quantitative thresholds":

(i) $\$ 50$ billion in total consolidated assets; (ii) $\$ 30$ billion in gross notional credit default swaps outstanding for which a nonbank financial company is the reference entity; (iii) $\$ 3.5$ billion of derivative liabilities; (iv) $\$ 20$ billion in total debt outstanding; (v) 15 to 1 leverage ratio of total consolidated assets (excluding separate accounts) to total equity; and (vi) 10 percent short-term debt ratio of total debt outstanding with a maturity of less than 12 months to total consolidated assets (excluding separate accounts). ${ }^{135}$

Generally, FSOC will evaluate nonbanks in Stage 2 only if they meet both the first threshold (consolidated assets) and one of the additional five thresholds. ${ }^{136}$ FSOC justified its selection and specification of these Stage 1 quantitative thresholds in terms of their predictive capacity and their practicality. ${ }^{137}$ In particular, FSOC noted that these thresholds apply meaningfully to nonbanks operating in a range of different industries, would have captured many of the nonbank financial firms that contributed significantly to systemic instability in the financial crisis, and could generally be assessed using publicly available information. ${ }^{188}$ Nonetheless, FSOC emphasized that this quantitative screen is ultimately "an imperfect mechanism to identify all nonbank financial companies of which further review is warranted." 139 For this reason, FSOC reserved the possibility that it might elevate a nonbank firm for Stage 2 review even if it does not satisfy this quantitative test. ${ }^{140}$

Those firms that pass through the Stage 1 quantitative screen are then subject to a Stage 2 evaluation, during which the council prioritizes its analysis of them. In doing so, the council relies on "a wide range of quantitative and qualitative information" that it extracts from publicly available and regulatory sources. ${ }^{141}$ Firms that pass the first two stages proceed to Stage 3,

\footnotetext{
135 Id at 21643 (formatting omitted).

13677 Fed Reg at 26143 (cited in note 123).

137 Id at 21641.

138 Id at 21643.

139 Id at 21642.

14077 Fed Reg at 21643 (cited in note 123).

141 Id at 21660.
} 
at which point they are informed that they are being considered for FSOC designation and invited to meet with council staff and submit relevant materials to the council. ${ }^{142}$ There are, it is worth noting, some benefits to the informal nature of these meetings, in which firms can get a sense of the concerns of the council and decide whether to address them in a way that would not be possible in a more formalized enforcement process.

3. FSOC's designations to date.

Under these procedures, FSOC has to date elevated nine nonbank financial firms to Stage 2 analysis and advanced either four or five of these to Stage 3 of the FSOC process. ${ }^{143}$ In total, FSOC has designated four nonbank financial companies as SIFIs. ${ }^{144}$ These include the country's three largest insurance-focused financial conglomerates-AIG, ${ }^{145}$ Prudential Financial, ${ }^{146}$ and MetLife ${ }^{147}$-and the financing arm of a major industrial corporation, General Electric Capital Corporation (GE). ${ }^{148}$

FSOC's designation of MetLife is illustrative of its designation process; the designation is also the most well documented due to MetLife's court challenge. ${ }^{149}$ MetLife was notified in July 2013 that it was under consideration by the council, meaning that the firm had passed the first two stages of designation. ${ }^{150}$ Over the next year, council staff met with MetLife's representatives twelve times and held five meetings with two state insurance authorities

142 Id at 21645 . We describe the Stage 3 procedure in more detail below, in connection with FSOC's designation of MetLife. See text accompanying notes 149-66.

143 See FSOC Nonbank Designation Process at *25 (cited in note 11).

144 See id.

145 See generally Financial Stability Oversight Council, Basis of the Financial Stability Oversight Council's Final Determination regarding American International Group, Inc. (July 8, 2013), archived at http://perma.cc/Q8GW-RK5X.

146 See generally Financial Stability Oversight Council, Basis for the Financial Stability Oversight Council's Final Determination regarding Prudential Financial, Inc. (Sept 19, 2013), archived at http://perma.cc/GDY6-VAC6.

147 See generally Financial Stability Oversight Council, Basis for the Financial Stability Oversight Council's Final Determination regarding MetLife, Inc. (Dec 18, 2014), archived at http://perma.cc/K2V2-MVK4.

148 See generally Financial Stability Oversight Council, Basis of the Financial Stability Oversight Council's Final Determination regarding General Electric Capital Corporation, Inc (July 8, 2013), archived at http://perma.cc/8KK3-D63T.

149 See MetLife, Inc $v$ Financial Stability Oversight Council, 177 F Supp 3d 219, 229 (DDC 2016).

150 MetLife Designation at *2 (cited in note 147$)$. 
with jurisdiction over MetLife's insurance subsidiaries. ${ }^{151}$ Additionally, MetLife submitted over twenty-one thousand pages of materials to the council. ${ }^{162}$

The council voted 9-1 to make a proposed designation of MetLife on September 4, 2014, and thereafter sent the company a notice and explanation of this determination. ${ }^{153}$ MetLife then contested the proposed determination, submitting written materials explaining its objections and further elaborating on them in a hearing before the full council on November 3 , after which more written materials were submitted. ${ }^{154}$ After considering these materials, the council by a vote of 9-1 officially designated MetLife. ${ }^{155}$ At that time, the council provided MetLife with a detailed statement of the basis for its decision, including nonpublic information provided by MetLife to the council.156

FSOC's public basis relied on the first determination standard, concluding that "material financial distress" at MetLife could produce financial instability. ${ }^{157}$ The council focused on the potential consequences of material financial distress at MetLife "in the context of a period of overall stress in the financial services industry and in a weak macroeconomic environment." 158 This vantage point, it explained, is "[c]onsistent with the Council's mission under the Dodd-Frank Act to identify potential threats before they occur," given that "financial crises can be hard to predict and can have consequences that are both far-reaching and unanticipated." 159

Material financial distress, the council determined, could be transmitted throughout the broader financial system through both the exposure and asset liquidation transmission channels. ${ }^{160}$ In reaching this conclusion, FSOC's public basis discusses each of the ten statutory factors in Dodd-Frank and the six categories contained in its final rule. For instance, the council emphasized that MetLife was the largest insurance provider in the US by several measures and is "significantly interconnected to insurance

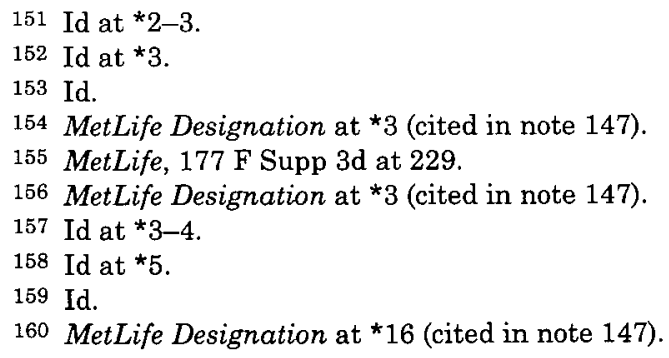


companies and other financial firms through its products and capital markets activities." ${ }_{161}$ These activities, including securities lending and the funding of agreement-backed notes, create liabilities "that increase the potential for asset liquidations by MetLife in the event of its material financial distress." 162 The council also noted that "MetLife's complexity, intra-firm connections, and potential difficulty to resolve" could aggravate the risk that financial distress at the company could impair financial market functioning. ${ }^{163}$ Additionally, while acknowledging that MetLife's operating insurers are subject to state insurance regulation, the council noted that this regulation is focused predominantly on protecting policyholders and does not include key elements of financial stability regulation, such as consolidated capital and liquidity requirements. ${ }^{164}$

\section{B. Key Characteristics of Nonbank SIFIs and the Residual Uncertainty in Identifying These Firms}

Notwithstanding the apparent complexity of FSOC's designation regime, the distinction between nonbank financial firms that are systemically significant and those that are not is both murky and indeterminate. To be sure, broad agreement exists regarding many of the central characteristics of systemically risky nonbank financial firms. Each of the six categories specified in FSOC's final rule and guidance-(1) size; (2) interconnectedness; (3) substitutability; (4) leverage; (5) liquidity risk and maturity mismatch; and (6) existing regulatory scrutiny ${ }^{165}$-are relevant to this inquiry. Indeed, some subset of these factors helps to explain each failure of a major nonbank financial firm that helped stoke the financial crisis. For instance, every one of these factors, other than substitutability, was arguably implicated in the demise of Lehman Brothers and Bear Stearns. As discussed in Part I, these entities were large, highly leveraged companies that relied on short-term debt and were deeply interconnected with the rest of the financial system. ${ }^{166}$ But they were regulated primarily by the

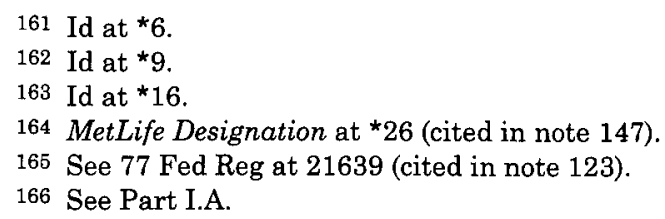


SEC, which viewed its mission predominantly in investor protection rather than financial stability terms. ${ }^{167}$ The factor of "substitutability" was most obviously exemplified by the GSEs, which provided essential and irreplaceable support to the real estate market through their loan guarantees and purchases. ${ }^{168}$ Of course, the GSEs were also leveraged to the hilt, relied on shortterm financing, maintained massive balance sheets, and were subject to inadequate regulatory oversight. ${ }^{169}$

Additionally, many experts would probably agree that two of FSOC's six categories-(1) liquidity risk and maturity mismatch and (2) existing regulatory scrutiny-deserve special emphasis because they define the basic parameters of "shadow banking." Shadow banking is best defined as (i) short-term liabilities (ii) backing potentially illiquid assets (iii) when the traditional restrictions and backstops of bank regulation are not present. ${ }^{170}$ The first two factors describe what any bank does, and the third expresses the fact that the shadow bank is not regulated as a bank. Shadow banking played a particularly important role in the crisis, allowing spooked creditors to "run" on financial institutions like Lehman, in much the same way that depositors can run on a bank by withdrawing deposits. ${ }^{171}$ There is good reason to believe that such runs-which can generate self-reinforcing and contagious panic-constitute the sine qua non of systemic risk. ${ }^{172}$

The assessment of any particular firm's systemic significance, however, is inherently subject to substantial uncertainty.

167 See Lawrence A. Cunningham and David Zaring, The Three or Four Approaches to Financial Regulation: A Cautionary Analysis against Exuberance in Crisis Response, 78 Geo Wash L Rev 39, 59-62 (2009). As described in Part I, the same set of five factors were instrumental in explaining AIG's systemic implications: AIG was a massive financial conglomerate whose CDS portfolio and securities-lending operations resulted in off-balance sheet leverage, massive interconnections with the rest of the financial system, and substantial maturity mismatch. Neither state insurance regulators nor the OTS adequately regulated the company on a consolidated basis by either. See Part I.

168 See Solomon and Zaring, 95 BU L Rev at 378-87 (cited in note 77).

169 See id.

170 See Gary Gorton and Andrew Metrick, Regulating the Shadow Banking System *269 (Brookings Papers on Economic Activity No 2, Oct 18, 2010), archived at http://perma.cc/4JCS-8CN6. See also Zoltan Pozsar, et al, Shadow Banking, 19 Fed Reserve Bank NY Econ Pol Rev 1, 1-3 (Dec 2013); John Armour, et al, Principles of Financial Regulation 445-48 (Oxford 2016).

171 See Gorton and Metrick, 104 J Fin Econ at 426-27 (cited in note 56).

172 See Morgan Ricks, The Money Problem: Rethinking Financial Regulation 165 (Chicago 2016) (observing that a run at one bank may become a focal point for runs at other banks, exposing the economy to disaster). 
Fundamentally, this is because whether or not a firm is systemically significant depends on a nearly infinite array of variables that are impossible to anticipate with anything resembling precision. ${ }^{173}$ For instance, the impact of a firm's financial distress on the broader financial system depends not only on the behavior of the firm's creditors, counterparties, and regulators, but also-and to a much larger extent-on these responses' secondary effects on other actors in the broader financial system. And that, in turn, would be influenced by these secondary actors' ever-changing perceptions of the financial system's health, not to mention the actions of lawmakers and regulators. Accurately anticipating each of these factors would require one arbitrary assumption after another. ${ }^{174}$

Revisiting regulators' understanding of Lehman Brothers during the financial crisis illustrates this point vividly. Although regulators had varying views regarding whether Lehman could or should be bailed out, hardly anyone predicted that allowing the firm to fail would trigger the sequence of events that followed its bankruptcy filing. ${ }^{175}$ Yet Lehman's failure was perhaps the financial crisis's single most dramatic accelerant, directly causing a series of unexpected knock-on events, including the freezing of the commercial-paper market and runs on money market mutual funds. ${ }^{176}$ The nation's leading financial regulators, in other words, could not anticipate the impact of Lehman's failure on the financial system immediately before it occurred-in spite of their knowledge of Lehman's balance sheet at that time, as well as the state of the broader economy and financial system. In light of this reality, it is simply unrealistic to expect that FSOC or anyone else could correctly anticipate the precise impact of a firm's financial distress as a result of hypothetical, future losses incurred under unknown financial and economic conditions. Because financial crises are so unpredictable, the margin of error that supervisors need must be capacious.

173 This point has been emphasized by critics of FSOC. See, for example, The Growth of Financial Regulation and Its Impact on International Competitiveness, Hearing before the Subcommittee on Oversight and Investigations of the House Committee on Financial Services, 113th Cong, 2d Sess 62 (2014) (statement of Peter J. Wallison, American Enterprise Institute) (" $I]$ t is impossible to know whether a particular institution's 'distress' would cause instability in the US financial system.").

174 See John C. Coates IV, Cost-Benefit Analysis of Financial Regulation: Case Studies and Implications, 124 Yale L J 882, 997-99 (2015).

175 See Bernanke, The Courage to Act at 248-69 (cited in note 61 ).

176 See The Financial Crisis Inquiry Report at *324-44 (cited in note 58). 
Even putting to one side the inherent uncertainty involved in determining which nonbanks could pose a risk to the broader financial system, there still remains a good deal of indeterminacy about the best way to assess which particular nonbanks are most likely to be systemically significant for at least three reasons. First, there is currently limited consensus about the complete set of firm-specific characteristics that are relevant to diagnosing systemic risk. For instance, it is hardly clear that the six categories identified by FSOC represent an exhaustive list of relevant factors or an ideal framing of these factors. Indeed, FSOC itself has suggested that an additional relevant factor involves the complexity and resolvability of a financial institution, reflecting both the emphasis in other parts of Dodd-Frank on promoting the quick and orderly resolution of failing firms and the lack of any such orderly resolution mechanism in the case of Lehman Brothers. ${ }^{177}$ Similarly, internationally developed frameworks for assessing the systemic risks posed by nonbank financial firms emphasize other factors, such as the number of different countries in which a firm operates, as well as a firm's involvement in specific activities that are "non-traditional" for firms in that sector. ${ }^{178}$

Second, myriad questions remain about how to measure or assess those factors that are clearly centrally important to identifying systemically risky nonbanks. Some relevant factors-such as existing regulatory scrutiny and substitutability-are not readily susceptible to reliable quantitative assessment. ${ }^{179}$ Their appraisal will therefore inevitably vary on the perspectives and assumptions of the assessor. Moreover, many of the other relevant factors can be assessed quantitatively in a large variety of ways, none of which perfectly captures the linkage between the relevant characteristic and systemic risk concerns. For instance, FSOC itself identifies seven different potential measures of interconnectedness, four potential measures of leverage, and seven different measures of maturity mismatch. ${ }^{180}$ Even the seemingly straightforward category of size can be measured in multiple ways, ranging from total consolidated assets to total consolidated liabilities to total risk in force. ${ }^{181}$ Making matters

177 See text accompanying notes 128-29.

178 See International Association of Insurance Supervisors, Global Systematically Important Insurers: Initial Assessment Methodology *12 (July 18, 2013), archived at http://perma.cc/A85S-5353.

179 See 77 Fed Reg at 21639 (cited in note 123).

180 See id.

181 See id. 
even more complicated, the most appropriate measurement of any particular factor will in most cases depend on numerous secondary considerations.

Third, even among the firm characteristics that are broadly recognized as relevant to the systemic risk inquiry-such as the six FSOC categories-and that can be reliably measured, there is no single agreed-on approach to assessing their relative importance. ${ }^{182}$ As above, it is likely that the relative importance of any particular firm's characteristics itself depends on the broader context. ${ }^{183}$ For instance, while (as suggested earlier) maturity mismatch is perhaps the most important characteristic of a SIFI, the systemic implications of this characteristic almost certainly depend on size and interconnectedness as well. A run on a financial institution of any type will likely have limited systemic consequences if the institution is not big enough or interconnected enough to transmit panic elsewhere in the system. Thus, the run on Lehman and Bear resulted in broader panic predominantly because these institutions were large and so interconnected with the broader financial system. ${ }^{184}$

Not only is maturity mismatch not a sufficient condition for diagnosing nonbank SIFIs, it is also not a necessary condition. This point is easiest to see for institutions that serve fundamental and irreplaceable roles in the context of the larger financial system. For instance, the failure of GSEs like Fannie and Freddie would almost certainly generate immense financial instability even if they were not subject to any type of run, given the fundamental role that these institutions play in the mortgage markets. ${ }^{185}$ Moreover, it is hardly inconceivable that an institution could prove systemically risky even if it was not subject to a

182 Some international bodies have attempted to specify relative weights to systemic risk factors. For instance, the International Association of Insurance Supervisors specifies the relative weights of each of its risk factors, devoting primary weight to interconnectedness and the firm's participation in nontraditional activities. See Global Systematically Important Insurers at * 12 (cited in note 178). This latter category includes activities that create an asset-liability mismatch, but might also include a number of other activities. See generally id.

183 See 77 Fed Reg at 21639 (cited in note 123) (noting that each firm can pose systemic risks in unique ways).

184 See Part I.A. Similarly, the run on AIG would likely not have been systemically significant were it not for AIG's sheer size, as well as the fact that its major counterparties in both its CDS and securities-lending portfolios were many of the other largest financial institutions in the country. Even the run on the Prime Fund would not have produced the panic that it did if investors did not reasonably believe that the fund's portfolio of investments was likely correlated with the investments of most other money market funds.

185 See Davidoff and Zaring, 61 Admin L Rev at 484-91 (cited in note 53). 
clear "run" by short-term creditors. This possibility was arguably illustrated by the savings and loan (S\&L) crisis, which dragged on for years without any acute period of destabilizing runs and nonetheless required massive bailouts to avoid potentially grave damage to the larger macroeconomy. ${ }^{186}$

For all these reasons, it is currently not possible to precisely define when nonbank firms may pose systemic risks to the broader financial system. FSOC itself comes close to acknowledging as much, explaining that it is not possible to "reduce[] to a formula" the identification of firms as systemically significant "due to the unique threat that each nonbank financial company may pose to U.S. financial stability and the qualitative nature of" many of the relevant factors. ${ }^{187}$ But the difficulty is even greater than this acknowledgement suggests: ultimately the process of identifying nonbank SIFIs is inherently indeterminate and contestable, at least with respect to the subset of firms that fall relatively close to the border in either direction.

These conclusions are reflected by an independent assessment of FSOC's designation process by the nonpartisan Congressional Research Service (CRS). This review, which included both public designations as well as confidential memoranda explaining FSOC's basis for declining to advance to Stage 3 various nonbank firms, was unable "to replicate that the FSOC's process was more likely to designate a firm if it posed a greater threat to financial stability than if it did not." 188 This result followed naturally from the fact that FSOC's "documents did not include a framework for combining different sources of financial stability into a standard that could be used to distinguish between

186 See generally Timothy Curry and Lynn Shibut, The Cost of the Savings and Loan Crisis: Truth and Consequences, 13 FDIC Bank Rev 26 (Fall 2000). The S\&L crisis refers to a period between the mid-1980s and mid-1990s when thrift depository institutions failed in historically unprecedented numbers. The primary source of these failures was home loans that thrifts had made earlier to borrowers at fixed interest rates. These fixed interest rates on the thrifts' assets ended up being lower than the very high interest rates that thrifts had to pay to their depositors to remain competitive. Thrifts thus ended up borrowing money from their depositors at a higher rate than they invested them. During the early years of the crisis, regulators failed to shut these failing thrifts down, allowing them to attempt to grow their way out of their troubles and take on more risk in the process. Ultimately, over one thousand thrifts, holding more than $\$ 500$ billion in assets, failed during this time period. See Michael S. Barr, Howell E. Jackson, and Margaret E. Tahyar, Financial Regulation: Law and Policy 54-55, 167-71 (Foundation 2016).

18777 Fed Reg at 21641-42 (cited in 123).

188 FSOC Nonbank Designation Process at *9 (cited in note 11) (reproducing a portion of the CRS memo). 
firms." 189 At the same time, the CRS review did indeed affirm that FSOC's analysis of individual firms "in isolation" each generally identified "plausible threat[s] to financial stability." 190

\section{REGULATION BY THREAT: THE LOGIC OF FSOC'S REGULATORY ARCHITECTURE}

Parts I and II raise a seemingly intractable problem of regulatory design. How can nonbank firms like Prudential be prevented from becoming systemically risky when this risk is ever changing, nonbank firms have more incentive than ever to affirmatively seek out systemic risk, and regulators do not know precisely how to diagnose systemically risky nonbanks? This Part argues that FSOC's designation regime solves this challenge by operating as a dual threat against both individual firms that would seek out systemic risk and their primary regulators who might permit this to happen under their watch.

Part III.A develops the first point, showing how FSOC's designation power combined with its refusal to reduce designation to a simple formula or to articulate firm-specific "off-ramps" for designation prevents nonbank firms from seeking out systemic risk. The reason, we argue, is that the threat of designation-and the "enhanced supervision and prudential standards"191 that come along with it-deters firms from embracing strategies that could render them systemically significant. This is clearly evidenced by the actions of firms that have been designated as systemically significant to date. To be sure, the amorphous nature of FSOC's designation regime creates uncertainty for some firms on the borderline of the systemic risk designation. ${ }^{192}$ But this uncertainty is a necessary downside of an FSOC regime whose primary goal is not to correctly identify every systemically significant nonbank firm but is instead to reliably prevent most nonbank firms from taking on the pre-crisis systemic risk profiles of firms like AIG, Lehman

$189 \mathrm{Id}$.

190 See id.

191 Dodd-Frank Act $\S 165,124$ Stat at $1423-32,12$ USC $\S 5365$.

192 As we suggest later, the actual scope of this uncertainty is not as significant as many FSOC critics suggest. See Part IV. 
Brothers, or Bear Stearns. In this sense, the FSOC regime of regulation by threat is one way of implementing the precautionary principle. ${ }^{193}$

As applied here, FSOC's use of the designation threat to instill caution in firms leaves regulators with a margin of safety, even if they cannot forecast with great reliability which specific nonbank financial institutions will be implicated in the next financial crisis; as we have observed, the council's context is precisely the sort of area in which observers like Professor Sunstein-no fan of the precautionary principle in most casesfinds a variant of it to be compelling. ${ }^{194}$ While this Part focuses on the effectiveness and necessity of the FSOC designation regime as regulation by threat, we reserve to Part IV the related issue of whether this method is a legitimate way to approach a regulatory enterprise.

Part III.B then turns to the second element of FSOC's dual threat, describing how FSOC's designation authority allows it to operate as an effective and credible watchdog over nonbank firms' primary financial regulators. As noted above, Dodd-Frank created new rules for both certain specific nonbank financial companies, such as hedge funds, and for financial activities that are engaged in by a variety of different types of nonbanks, such as derivatives trading. But these rules require extensive development and enforcement, leave unaddressed key issues, and will inevitably be gamed by firms. FSOC's designation authority threatens nonbank firms' primary regulators with the prospect of losing

193 We, like most of the world's scientists and the World Trade Organization's Appellate Body, find the European Union's invocation of the precautionary principle to ban imports of beef treated with hormones from the United States to be unpromising. See, for example, European Communities-Measures concerning Meat and Meat Products (Hormones), World Trade Organization, Report of the Appellate Body (Jan 16, 1998), WT/DS26/AB/R \& WT/DS48/AB/R 45-46 at I 1 123-25 (describing the role of the precautionary principle in international law and finding that the principle could not defeat plain treaty language); Joost Pauwelyn, The Role of Public International Law in the WTO: How Far Can We Go?, 95 Am J Intl L 535, 569-70 (2001) (arguing that the World Trade Organization decision was "correct"). On the other hand, no one doubts that some applications of a precautionary principle are appropriate, such as the old rule of thumb about the criminal justice system-better that ten guilty men go free rather than one innocent man be convicted. See generally Alexander Volokh, n Guilty Men, 146 U Pa L Rev 173 (1997). But see generally Daniel Epps, The Consequence of Error in Criminal Justice, 128 Harv L Rev 1065 (2015).

194 Sunstein, 91 Cornell $L$ Rev at 845 (cited in note 29) ("When regulators lack information about the likelihood and magnitude of a risk, it makes sense to spend extra resources to buy an 'option' to protect against irreversible harm until future knowledge emerges."). 
regulatory turf to the Fed if they fail to effectively develop, enforce, and fill in these rules, both in the near term and in the future. Here again, we suggest that this fact is clearly evidenced by various regulatory reforms that have evolved since Dodd-Frank's passage.

\section{A. FSOC Designation and Firm-Level Deterrence}

In order to deter nonbank systemic risk, FSOC designation must not only impact firms' behavior, but do so in a way that is likely to reduce their prospect of contributing to a financial crisis. We address these two components in turn. Part III.A.1 shows that the threat of FSOC designation has clearly impacted large nonbanks' strategies, activities, and structures. Part III.A.2 then argues that these shifts meaningfully reduce nonbanks' systemic riskiness.

\section{The deterrent force of designation.}

As implemented and applied, the FSOC designation regime incentivizes nonbanks to eschew activities and strategies that they anticipate would subject them to designation. This is a direct result of the panoply of mandatory enhanced prudential standards imposed on systemically important firms, including requirements relating to risk-based capital, liquidity, risk management, resolution planning, single-counterparty credit limits, and stress tests. ${ }^{195}$ These rules have the obvious potential to impose huge costs on designated firms, both in terms of (i) direct compliance costs and (ii) binding restrictions that would alter the firms' decisions and strategies. ${ }^{196}$ Indeed, Dodd-Frank itself specifies that the rules for nonbank SIFIs must be "more stringent"197 than those that apply to nondesignated firms. ${ }^{198}$

However, the actual costs to designated firms of these enhanced prudential standards depend crucially on how much more stringent they are than the prudential rules that the nonbank would otherwise face. Firms that are already subject to the types of regulation and supervision that Dodd-Frank imposes on

195 See Part II.A.

196 See Skinner, 105 Georgetown L J at 1397-1408 (cited in note 47) ("This kind of regulation is not only expensive ... but it is also operationally intrusive and potentially disruptive to a firm's investor (and other) relationships.").

197 Dodd-Frank Act $\S 115(\mathrm{a})(1)(\mathrm{A}), 124$ Stat at 1403, 12 USC $\S 5325(\mathrm{a})(1)(\mathrm{A})$.

198 See Part II.A. 
nonbank SIFIs might well believe that the marginal costs of designation would be minimal. By contrast, the marginal costs stemming from designation would be large indeed with respect to nonbanks that are very lightly regulated in their baseline regime.

For nonbanks that are not substantially engaged in the business of insurance, the costs and constraints of the enhanced prudential standards resulting from FSOC designation are almost certain to be immense. This is because these firms' ordinary regulatory regimes are focused predominantly on investor protection, with only limited prudential rules that are different in kind from those accompanying designation. For instance, while brokerdealers are subject to capital requirements, they are not risk based, and regulators do not affirmatively monitor brokerdealers' capital levels. ${ }^{199}$ Similarly, broker-dealers are not ordinarily subject to liquidity requirements, stress tests, or resolution planning requirements. ${ }^{200}$ The same basic points apply to investment advisors and the various different types of pooledinvestment vehicles, such as mutual funds and hedge funds, which have not traditionally been subject to risk-based capital requirements, stress tests, or resolution planning. ${ }^{201}$

Although the marginal costs of enhanced prudential standards flowing from designation are less obvious for firms predominantly engaged in insurance, they are nonetheless almost certain to be quite large in this setting, as well. Unlike most nonbanks, insurers are indeed subject to most-though not all ${ }^{202}$ - of the types of mandated prudential standards applicable to designated firms, including risk-based capital rules, stress tests, investment restrictions, and single-counterparty credit limits. ${ }^{203}$ But even

199 See Carnell, Miller, and Macey, The Law of Financial Institutions at 130-36 (cited in note 46 ).

200 Margin requirements may act as a substitute for capital rules. See id.

201 The SEC has long imposed liquidity and leverage restrictions on registered funds, though these rules do not apply to unregistered funds like hedge funds. However, FSOC has recently questioned the robustness of these restrictions for registered funds for purposes of financial stability. See Financial Stability Oversight Council, Update on Review of Asset Management Products and Firms *6-8 (Apr 18, 2016), archived at http://perma.cc/T8B9-YSVC.

202 State insurance regulation has limited liquidity-oriented requirements, though some of the financial monitoring that the NAIC performs for states arguably promoted liquidity. State insurance regulation also lacks clear resolution-planning requirements analogous to a living will, although it does have an "Own Risk Solvency Assessment" that may partially serve an overlapping function. See generally Schwarcz, 5 UC Irvine L Rev 537 (cited in note 66).

203 See Kenneth S. Abraham and Daniel Schwarcz, Insurance Law and Regulation 104-72 (Foundation 6th ed 2015). 
apart from the specific content of these rules-which are still under construction-there is a crucial distinction between the prudential standards imposed by state insurance regulation and those required of systemically significant firms. Dodd-Frank requires all of its prudential requirements to apply across an entire consolidated financial entity. ${ }^{204}$ By contrast, essentially all of the prudential rules imposed by state insurance regulation focus exclusively on individual insurance companies, while ignoring their holding companies and noninsurer affiliates. ${ }^{205}$ Thus, the prudential regime imposed on insurance-focused nonbank SIFIs would indeed come along with a fundamentally different set of restrictions than those that exist in the baseline state regime.

The evidence to date strongly supports the conclusion that most nonbank financial firms have powerful financial incentives to avoid FSOC designation. ${ }^{206}$ Consider first market reactions to MetLife's successful challenge in district court to its designation. ${ }^{207}$ When the district court's decision was publicly released, MetLife's stock jumped around 5 percent, and the stock of Prudential, a fellow insurance-focused SIFI, advanced 1.6 percent. ${ }^{208}$ These stock-price increases likely understate the value to the firms of avoiding designation, as the judge had earlier indicated her skepticism of FSOC's designation, meaning that at least some of the benefit to MetLife of potentially winning its case was

204 See Schwarcz, 5 UC Irvine L Rev at 545 (cited in note 66).

205 See id. Dodd-Frank does allow for the creation of an intermediate financial holding company so that the prudential rules do not apply to legal entities not engaged predominantly in financial activities. Dodd-Frank Act $\S 113(\mathrm{c})(3), 124$ Stat at 1400,12 USC $\S 5323(\mathrm{c})(3)$.

206 This conclusion is not obvious. In fact, at least some firms have claimed in lawsuits that designation actually benefits the designated firms by sending the signal that these firms will not be allowed to fail. See State National Bank of Big Spring $v$ Lew, 795 F3d 48, 55 (DC Cir 2015) (rejecting on standing grounds this type of claim by a competitor of GE).

207 In addition to their efforts to avoid federal regulation as a result of designation, insurers have undoubtedly also sought to avoid regulation by the Fed that could result from being or owning a depository institution. Numerous insurers have thus divested themselves of their banking assets. As one lawyer has explained, "It's to get out from under federal regulation." Andrew Frye, Bank-Wannabe Insurers Switch Strategies to Avoid Oversight (Bloomberg, Aug 3, 2011), online at http://www.bloomberg.com/news/ articles/2011-08-03/bank-wannabe-insurers-seek-to-avoid-oversight (visited May 16, 2017) (Perma archive unavailable) (noting that "Hartford Financial Services Group Inc. struck a deal in May to sell the lender that it had acquired in 2009 to qualify for a bailout").

208 See Andrew M. Harris and Katherine Chiglinsky, MetLife Judge Called FSOC

Review Process 'Fatally Flawed' (Bloomberg, Apr 7, 2016), archived at http://perma.cc/YY44-R34H. 
already baked into its stock price. ${ }^{209}$ And even after the districtcourt opinion, there remains a reasonable chance that the decision may be overturned on appeal or else that FSOC might again attempt to designate MetLife.

Second, at least three of the four designated firms have seriously entertained proposals to radically alter their structure and activities in an effort to avoid the costs of designation. Consider MetLife, which, prior to successfully defeating its designation in district court, announced the sale of three of its insurers that sell variable annuities and the cessation of its future variable annuity sales. ${ }^{210}$ This "significant strategic shift" in the company's operations was driven substantially by MetLife's hope that it would assist the company in shedding its designation. ${ }^{211}$ Consistent with these explanations, MetLife has repeatedly claimed that its SIFI designation "risks [exposing it to] higher capital requirements that could put it at a significant competitive disadvantage." ${ }^{12}$

GE Capital has taken even greater steps to reduce its risk profile, an effort that was rewarded in June 2016 when it became the first firm to have its designation rescinded by FSOC. ${ }^{213} \mathrm{Be}-$ tween its designation and that time, GE Capital fundamentally transformed its business model. Most notably, it substantially reduced its reliance on commercial paper, thus largely eliminating its use of short-term financing. It also reduced its assets 52 percent, from $\$ 549$ billion to $\$ 265$ billion, largely exited the business of giving loans to consumers, and sold off its FDIC-insured subsidiaries as well as its commercial leasing business. ${ }^{214}$ Additionally, the firm dramatically reduced the number of its subsidiaries,

209 The change in stock price can be explained either by designation preventing firms from taking risks that they idiosyncratically would prefer to take or by designation imposing large compliance costs.

210 See Kerry Pechter, MetLife to Let VA Liabilities Go (Retirement Income J, Jan 14, 2016), archived at http://perma.cc/Q674-4XKR.

211 See MetLife Move Has Implications for Global Insurers (Fitch Ratings, Jan 13, 2016), online at http://www.fitchratings.com/site/pr/997834 (visited Aug 25, 2017) (Perma archive unavailable); John Heltman, MetLife to Break Itself $U p$, Citing Regulatory Environment' (Am Banker, Jan 12, 2016), online at http://www.americanbanker.com/news/ metlife-to-break-itself-up-citing-regulatory-environment (visited Aug 25, 2017) (Perma archive unavailable).

212 MetLife Announces Plan to Pursue Separation of U.S. Retail Business (MetLife, Jan 12, 2016), archived at http://perma.cc/F487-HTZS. See also MetLife to Ask Federal Court to Review SIFI Designation (MetLife, Jan 13, 2015), archived at http://perma.cc/RZ62-ZB92.

213 See generally Rescission of GE Determination (cited in note 17).

214 Id at *23. 
making the firm less complicated, and if necessary, easier to resolve. ${ }^{215}$ In granting GE Capital's request for de-designation, the council emphasized its "smaller size, . . . limited scale of activities in key funding markets, [and] decreased direct and indirect exposures."216

AIG has also fundamentally altered its structure in order to achieve de-designation. In 2015, activist investors Carl Icahn and John Paulson proposed that AIG become "a smaller, simpler company with a path to [de-designation]." ${ }^{217}$ In initially rejecting these proposals, AIG emphasized both the efficiencies of operating at a large scale as well as the "false premise" that breaking itself up would allow it to shed its SIFI designation. ${ }^{218}$ By contrast, it did not contest the costs to the firm of the enhanced prudential standards and supervision to which it is subject as a result of designation. ${ }^{219}$ But while it asserted the power to reject overtures to restructure, it did alter its business substantially, reducing headcount by half from its 2008 highs and selling nearly $\$ 100$ billion of assets, including life insurance businesses, to its rival MetLife. 220 Its progress on restructuring itself-alongside the change in FSOC's composition resulting from the 2016 electionled to its de-designation in 2017, the second de-designation made by the council, after GE Capital. ${ }^{221}$

2. Firm-level deterrence and the reduction of systemic risk.

Both theory and evidence therefore suggest that FSOC's designation regime causes nonbank firms to avoid strategies that they believe are likely to expose them to designation as a SIFI. To critics, however, this conclusion only raises the further question whether nonbank firms' changes in behavior actually reduce systemic risk, and at what cost. Critics often contend that it is difficult for nonbank firms to discern meaningful guidance from

215 See GE Capital Files Request for Rescission of Status as a Systemically Important Financial Institution (GE, Mar 31, 2016), archived at http://perma.cc/BS9Q-AT9K.

216 Rescission of $G E$ Determination at * 8 (cited in note 17$)$.

217 Cark Icahn, Open Letter to AIG Board (Jan 19, 2016), archived at http://perma.cc/3YE8-8QGL.

218 Stephen Gandel, AIG CEO: Carl Icahn's Breakup Plan Is Based on a False Premise (Fortune, Jan 26, 2016), archived at http://perma.cc/529P-2KC7.

219 See generally id.

220 See Sonali Basak and Katherine Chiglinsky, AIG Finds 'Safer Harbor' after Years of Retrenchment, Regulation (Bloomberg, Oct 2, 2017), archived at http://perma.cc/2LH5 -DGKS.

221 See generally Rescission of AIG Determination (cited in note 19). 
FSOC's decisions and broad framework. ${ }^{222}$ As a result, nonbank firms must frequently resort to guessing about what activities or strategies FSOC might believe would make them systemically risky. Not only does this produce substantial market uncertainty for firms, but it may well deter activities and strategies that FSOC itself might not believe to be systemically risky were it to consider the issue carefully in the context of the specific firm at issue. AIG's initial resistance to shareholders' break-up proposals illustrates this point well: AIG's management disputed that it could shed designation by breaking itself up, but analysis of this issue was simply guesswork. AIG was thus forced to make a major strategic decision on the basis of uncertain information about how its actions would be perceived by FSOC.

Understanding FSOC designation as regulation by threat suggests that these concerns, while eminently reasonable, are both inevitable and of second-order importance. This is because the key benefit and purpose of FSOC designation does not involve its impact on firms that are close to the murky and indeterminate line separating systemically risky firms from those that are not systemically risky. Instead, the key benefit of FSOC designation is that it reliably prevents nonbank firms from making business decisions in the future that will result in them being firmly on the systemically risky side of this dividing line. With FSOC's designation regime in place, there is little risk that any nonbank firm will take on the pre-crisis systemic risk profiles of AIG or the large investment banks like Lehman or Bear. ${ }^{223}$ This is particularly important given the point, developed above, that-in the absence of countervailing regulatory initiatives-the 2008 bailouts gave nonbank firms both an affirmative incentive to seek out systemic risk and a road map for how to accomplish this. ${ }^{224}$

The very same standard-like malleability of FSOC designation that generates the ire of FSOC's critics is essential to ensuring that FSOC designation achieves this primary goal of deterring nonbank firms from seeking to become the next AIG, Lehman, or Bear. Although FSOC's embrace of a malleable standard, rather than a formulaic rule, does indeed create uncertainty for nonbank

222 See generally, for example, FSOC Nonbank Designation Process (cited in note 11).

223 One important exception here involves the GSEs. But these are a special case because they are under conservatorship and are generally viewed as being essential to the mortgage market in their present form. Moreover, the ongoing debate about how to reform their role in the mortgage markets has seemingly exempted them from designation as SIFIs by FSOC.

224 See Part I.B. 
firms close to the line of designation, it also makes the FSOC regime relatively resistant to the type of regulatory arbitrage that was so prominent among nonbanks in the run up to the crisis. ${ }^{225}$ As with all standards, FSOC's relatively flexible and adaptive designation standard empowers its members to look past any attempts by firms to recharacterize transactions, activities, or products in a way that will generate systemic risks. ${ }^{226}$ To be sure, the council's capacity to accomplish this depends on its level of knowledge, expertise, and understanding. But if the members of FSOC-the leading experts on financial regulation in the country, supported by the resources of each of their member agencies-cannot detect a firm's efforts to exploit regulatory loopholes or blind spots, then there is little hope that anyone else could reliably do so.

Like any common-law court, or any agency that acts through adjudication rather than rulemaking, for that matter, the council has chosen to identify risk beyond the pale on a case-by-case basis. The fact that uncertainty exists at the beginning of the process of fleshing out a new policy program is not a reason to forbid courts and regulators from taking things one case at a time. $\mathrm{Ra}$ ther, the discretion that agencies have to choose between rulemaking and adjudication is one of the fundamental principles of administrative law. 227

In fact, we believe that FSOC's designation decisions to date amply demonstrate FSOC's capacity to use its broad framework to target activities and strategies that exploit regulatory arbitrage in ways that may create new forms of systemic risk. Consider just one example. In its designations of Prudential, AIG, and MetLife, FSOC highlighted these firms' use of captive reinsurance transactions, also known as "shadow insurance." 228 In these transactions, an insurer purchases reinsurance from an affiliated

225 See Part II.A. See also Examining Insurance Capital Rules and FSOC Process, Hearing before the Subcommittee on Securities, Insurance, and Investments of the Senate Committee on Banking, Housing, and Urban Affairs, 114th Cong, 1st Sess 7 (2015) (statement of Professor Daniel Schwarcz).

226 See generally Louis Kaplow, Rules versus Standards: An Economic Analysis, 42 Duke L J 557 (1992).

227 See, for example, National Labor Relations Board v Bell Aerospace Co, 416 US 267, 294 (1974) (explaining that an agency "is not precluded from announcing new principles in an adjudicative proceeding and [] the choice between rulemaking and adjudication lies in the first instance within the Board's discretion").

228 See generally Daniel Schwarcz, The Risks of Shadow Insurance, $50 \mathrm{Ga} \mathrm{L} \mathrm{Rev}$ 163 (2015). 
company that is subject to more limited regulatory scrutiny because it is organized as a "captive insurer" rather than an ordinary insurer. ${ }^{229}$ State regulators generally allow the insurer to treat this claim from its affiliate as reliable only if it is supported by a third-party guarantee. But these guarantees are often supplied by banks, in the form of a letter of credit. These banks, moreover, frequently retain the right to look to the parent company of the insurers or one of their affiliates for repayment if the letter of credit is triggered.

As one of us has argued extensively in other work, these shadow insurance transactions represent a form of regulatory arbitrage that has the potential to result in large insurance-focused entities becoming systemically risky. ${ }^{230}$ For instance, they expose insurers to substantial asset-liability mismatch risk because the letters of credit that back these transactions are generally relatively short-term, even though the underlying liabilities they back are long term. They also increase interconnectedness risk by increasing the connections between the insurance and banking sectors. Perhaps most obviously, they increase the complexity and resolvability of large insurance firms. By targeting these shadow insurance transactions in its designations of insurance-focused nonbanks, FSOC illustrates how its standard for designation can be used to counteract new and emerging forms of regulatory arbitrage that have the potential to render a nonbank firm systemically risky. ${ }^{231}$

Perhaps even more importantly, FSOC can effectively deter nonbank firms from seeking out systemic risk through regulatory arbitrage even if it misses some systemically risky forms of such arbitrage while incorrectly identifying others. So long as FSOC presents a credible threat to nonbanks that systemically risky arbitrage strategies will result in designation, it will deter efforts by firms to test this system. As amply illustrated by financial firms' complaints regarding the uncertainty generated by FSOC's

229 Id at 166.

230 See id at 164-65, 207. See also generally Ralph S.J. Koijen and Motohiro Yogo, Shadow Insurance, 84 Econometrica 1265 (2016); Ralph S.J. Koijen and Motohiro Yogo, Risk of Life Insurers: Recent Trends and Transmission Mechanisms, in Felix Hufeld, Ralph S.J. Koijen, and Christian Thimann, eds, The Economics, Regulation, and Systemic Risk of Insurance Markets ch 4 (Oxford 2016).

231 A consolidated regulatory capital standard, such as that proposed by the Fed for designated firms in its Advanced Notice of Proposed Rulemaking, see note 115, would eliminate the regulatory arbitrage benefits of shadow insurance because firm capital would be insensitive to the placement of individual assets and liabilities in different legal entities within the larger conglomerate. 
designation regime, financial firms have strong reasons to avoid regulatory uncertainty, which can threaten not only the standard regulatory costs but also negative publicity and executives' jobs.

Contrary arguments that FSOC's designation regime will affirmatively prompt regulatory arbitrage are, we believe, unpersuasive. For instance, Professor Christina Skinner has suggested that the binary nature of the FSOC designation standard will lead firms to engage in regulatory arbitrage to avoid designation. ${ }^{232}$ In particular, Skinner suggests that the extreme consequences of designation will cause some firms to shop for an alternative regulator other than the Fed and then attempt to claim that designation is not warranted because they are already adequately regulated. ${ }^{233} \mathrm{We}$ find this argument unconvincing, because FSOC has the authority to designate any nonbank financial firm as a SIFI, irrespective of who that firm's regulator is. As such, the only way that a firm could decrease its chances of being designated by shopping for a regulator would be if FSOC deemed that regulator to be effective with respect to systemic risk. This point is amply illustrated by the MetLife case, in which FSOC specifically rejected MetLife's arguments that it was sufficiently regulated by noting the ways in which state insurance regulation does not address systemic stability. ${ }^{234}$ More generally, the standard-like nature of the relevant criterion-which examines the adequacy of existing regulation-limits the capacity of firms to rely on arbitrage strategies involving regulator shopping to avoid FSOC designation.

Because of the uncertainties of predicting the future in finance-an art that no one has been able to master with any reliability - there is little doubt that FSOC will err on occasion in its assessment of whether any particular nonbank is systemically significant or in its explanation for this conclusion. But there is not, at the present time, any reasonable alternative for definitively determining when a nonbank is systemically significant, and any attempt to devise such a test would ultimately suffer the same fate as the pre-crisis distinction between banks and nonbanks. ${ }^{235}$

232 See Skinner, 105 Georgetown L J at 1401-02 (cited in note 47).

233 See id at 1402.

234 See MetLife Designation at *26-29 (cited in note 147).

235 To be sure, there are a large number of quantitative tests that aim to measure systemic risk, such as SRisk. See generally Monica Billio, et al, Econometric Measures of Connectedness and Systemic Risk in the Finance and Insurance Sectors, $104 \mathrm{~J}$ Fin Econ 535 (2012); Viral Acharya, Robert Engel, and Matthew Richardson, Capital Shortfall: A New Approach to Ranking and Regulating Systemic Risks, 102 Am Econ Rev 59 (May 
More importantly, understanding FSOC's designation process as regulation by threat means that it does not actually need to be completely accurate to achieve its broader purpose of preventing nonbanks from becoming systemically risky. Assuring precision in placing each financial institution on the correct side of the riskiness line is less important than the ability of FSOC to draw a line with a margin of safety.

Actually achieving the broader purpose of FSOC's designation regime-reduction of systemic risk outside of the banking system -is of paramount importance. Regulatory scrutiny should be particularly high in the face of substantial uncertainty about the costs of the conduct being regulated, along with the substantial prospect of an extreme downside. ${ }^{236}$ As Professor Hilary Allen has observed, precautionary approaches make particular sense when it comes to financial regulation; she argues that "financial regulatory agencies should take a precautionary approach in drafting and implementing rules that relate to financial stability, and the courts should show deference when reviewing precautionary acts by financial regulatory agencies." ${ }^{237}$

\section{B. FSOC Designation and the Adaptation of Primary Financial Regulations}

The big stick of designation not only deters financial firms from seeking out excessive risk; it also deters primary regulators of nonbanks from shirking in their efforts to account for systemic risk. Shirking could come in the form of primary regulators' lackluster efforts to implement or enforce Dodd-Frank's reforms aimed at limiting systemic risk outside of the banking sector, such as derivative clearinghouses or new reporting. rules for hedge funds. Alternatively, it might consist of failing to address issues left unresolved in Dodd-Frank, such as reform of GSEs or money market mutual funds. Perhaps most importantly, primary financial regulators might shirk by ignoring unanticipated

2012). Although these measures provide one important perspective on systemic risk, there is also little doubt that they cannot accurately and reliably distinguish between systemically significant institutions and those that are not systemically significant. See generally Lars Peter Hansen, Challenges in Identifying and Measuring Systemic Risk, in Markus Brunnermeier and Arvind Krishnamurthy, eds, Risk Topography: Systemic Risk and Macro Modeling 15 (Chicago 2014). This is precisely why no existing regulatory regime has tethered its approach to these quantitative measures, even if they consider them as one relevant factor in their analysis.

236 See Sunstein, Laws of Fear at 61 (cited in note 28).

237 Allen, 45 Loyola U Chi L J at 178 (cited in note 26). 
changes in financial markets that require a change in their regulatory approach.

As described in Part II, Dodd-Frank grants FSOC limited direct authority over primary financial regulators. ${ }^{238}$ FSOC's designation power nonetheless operates as an effective threat against primary financial regulators who refuse to follow FSOC's suggestions and do not offer a convincing explanation for this decision. This is because designation-while nominally aimed at specific nonbank firms-simultaneously operates as a deterrent to that firm's regulator by threatening to intrude on its regulatory turf. Even though FSOC designation does not strip a primary regulator of its authority over a designated firm, it no doubt diminishes the authority and power of that primary regulator. For instance, "more stringent" prudential rules imposed by the Fed as a result of designation will in many cases obviate parallel restrictions imposed by a firm's primary regulator, as firms must generally focus their compliance efforts on the most stringent regulations they face. Relatedly, enhanced regulation by the Fed may effectively eliminate the capacity of a firm's primary financial regulators to grant that firm waivers or exemptions to regulatory requirements, or to approve nonstandard transactions or activities. Few agencies relish the prospect of losing control over firms and industries that they traditionally regulate, so this constraint is a real one.

FSOC designation of a firm threatens to intrude on the power and authority of the firm's primary regulator in a second, and distinct, way. Recall that FSOC designation comes along not just with enhanced prudential standards crafted by the Fed, but also with enhanced supervision conducted by the Fed. ${ }^{239}$ As a result, many of the decisions that a primary financial regulator makes in connection with its supervision of a designated firm are indirectly subject to oversight and assessment by the Fed itself. If, for instance, a primary regulator approves a designated firm's accounting treatment of a transaction, but the Fed does not, then the implicit (or perhaps explicit) message is that the primary financial regulator erred. In a very real sense, then, the Fed becomes the supervisor of both the designated firm itself and that firm's primary financial regulator.

238 See Part II.A.1.

239 See Part II.A.2. 
FSOC would also have good reason to respond to a primary financial regulator's refusal to adopt its recommendations by designating some of the firms that the regulator oversees. As discussed above, existing regulatory scrutiny is one of the six categories in FSOC's designation framework, and one of the ten Dodd-Frank categories. ${ }^{240}$ Thus, it would stand to reason that a primary financial regulator's refusal to accept an FSOC recommendation would increase the potential for the firms overseen by that regulator to be deemed systemically significant.

This capacity of FSOC's designation power to incentivize regulators to better account for systemic risk is perfectly illustrated by FSOC's successful campaign to induce the SEC to reform its regulation of money market funds. Recall the crucial role that money market funds played in the financial crisis. ${ }^{241}$ The industry nonetheless opposed new regulations, particularly those that might require it to adopt a "floating" net asset value, meaning that shares in the funds would vary in price based on the market value of the fund's underlying portfolio. Faced with this opposition, the SEC dithered. Enter the council. Pursuant to $\S 120$ of Dodd-Frank, it requested that the SEC redouble its efforts to pass regulation reforming the money market fund industry. ${ }^{242}$ The agency was not obligated to embrace the council's request, but it ultimately largely did so, adopting wide-ranging reforms of the basic type suggested by the council. ${ }^{243}$

In all likelihood, the SEC would have refused to accept FSOC's recommendations on money market funds were it not for the council's designation power. There is, in fact, strong evidence that the council had explicitly threatened the SEC with the prospect of designating large money market funds and their advisors. As the minutes for a 2012 FSOC meeting on money market funds indicated, the secretary of the treasury "urged the council to take parallel steps to consider authorities under Title I . . of the Dodd-Frank Act in the event that the SEC is unwilling to act

240 See Part II.A.2.

241 See Part I.A.

242 See Financial Services Oversight Council, Proposed Recommendations regarding Money Market Mutual Reform, 78 Fed Reg 4145, 4146 (2012).

243 See generally Securities and Exchange Commission, Money Market Fund Reform; Amendments to Form PF, 79 Fed Reg 47736 (2014), amending 17 CFR Parts 230, 239, 270, 274, 279. See also SEC Adopts Money Market Fund Reform Rules (SEC, July 23, 2014), archived at http://perma.cc/QP35-QFU6. 
in a timely and effective manner." ${ }^{244}$ Title $I$ is the part of the act in which the council's designation power lies. The Treasury Department urged the council to closely consider whether funds meet the criteria for designation. ${ }^{245}$ If nothing else, of course, FSOC would have had a ready-made case that these funds and their advisors are not subject to effective systemic-risk regulation if the SEC had failed to act. ${ }^{246}$

To be sure, the fact that FSOC's voting members include the heads or chairs of the various nonbank financial regulators may well complicate FSOC's ability to effectively deter shirking among these agencies. These FSOC members may seek to strategically leverage their votes and connections to limit the risk that any of the firms they oversee will be designated. For instance, the chairs of the National Credit Union Association (NCUA) and SEC might agree (tacitly or expressly) not to vote for designation of either agency's regulated firms. Indeed, the NCUA chairman has publicly reassured credit unions that they are extremely unlikely to be designated as a SIFI. ${ }^{247}$ Such statements could reflect a broader strategy on the part of the NCUA to deter FSOC from considering a credit union as a possible SIFI. The capacity of FSOC member agencies to derail designation of their regulated firms can also explain why the insurance industry has been a focus of FSOC to date: there is no federal agency that principally regulates insurers to block any effort to designate these firms.

244 See Minutes of the Financial Stability Oversight Council *6 (FSOC, Sept 28, 2012), archived at http://perma.cc/MLS2-7UDH.

245 Letter from Timothy Geithner to Members of the Financial Stability Oversight Council (Wall St J, Sept 27, 2012), archived at http://perma.cc/4R5W-KDH7.

246 To be sure, it is not entirely clear that the SEC did everything the council would have preferred. See Allen, 76 Ohio St L J at 1119 (cited in note 102) (describing the SEC's final product as "much more limited [in] scale than any of the FSOC's proposals").

The SEC has also apparently been influenced by FSOC-and its capacity to designate firms subject to the SEC's oversight-in connection with its newly proposed rules governing liquidity for mutual funds and exchange-traded funds. These rules, which were proposed in September 2015, are designed to improve liquidity management, increase disclosure about liquidity risk, and allow funds to implement mechanisms to pass on to redeeming investors the transactions costs associated with redeeming shares in order to eliminate any first-mover advantage. Although the link between FSOC designation and the SEC's actions is not perfectly clear, FSOC has suggested reforms of these types for asset managers. Moreover, the chairperson of the SEC has publicly acknowledged that "FSOC's current review of the potential risks to the stability of U.S. financial system of asset managers is a complement to the work we are now undertaking." See Mary Jo White, Enhancing Risk Monitoring and Regulatory Safeguards for the Asset Management Industry (SEC, Dec 11, 2014), archived at http://perma.cc/FJ57-AQ2X.

247 See MetLife Contesting SIFI Designation *1 (NAFCU, Oct 8, 2014), archived at http://perma.cc/CY9C-4P8Z. 
Although these complications may well limit FSOC's capacity to credibly threaten to designate a nonbank that is directly supervised by a member agency, they do not eliminate the deterrent threat of designation. After all, FSOC can, and has, designated firms without the unanimous support of its voting members. ${ }^{248}$ Moreover, any agreement among voting members to refrain from designating their regulated firms would ultimately be hard to maintain, as six of FSOC's ten voting members are not the primary safety-and-soundness regulators of any nonbank financial firms. ${ }^{249}$ Thus, a single defection by one of the four principal regulators of nonbanks with an FSOC vote-the NCUA, SEC, Commodities Futures Trading Commission (CFTC), or Federal Housing Finance Agency (FHFA)-could thwart any such agreement. Nor did the apparent objections of the SEC prevent FSOC from successfully prodding the agency to implement new rules governing the stability of money market funds, as we have observed. ${ }^{250}$

\section{THE LEGITIMACY OF REGULATION BY THREAT}

In this Part of the Article, we defend regulation by threat more generally as a legitimate regulatory tool, and in particular in the way the council has deployed it. We then expand on the ways that the structure of the council provides good-governance checks that make up for its relatively unfettered designation discretion. Finally, we discuss some of the implications for current policy debates that our analysis has for the council and its members.

\section{A. The Legitimacy of Regulation by Threat in Financial Supervision, and Elsewhere}

Supervising an industry by singling out some institutions for particularly rigorous regulation to, in part, convey a message to other institutions somewhat like them requires justification. The same goes with threats to replace regulators with the Fed. Our

248 For instance, the independent member with insurance expertise dissented from the council's designation of MetLife as a SIFI. See generally Views of the Council's Independent Member (cited in note 117).

249 This includes the secretary of the treasury, chairman of the Fed, comptroller of the currency, director of the Consumer Financial Protection Bureau, chairperson of the FDIC, and the independent member with insurance expertise.

250 See notes $242-47$. 
justification turns on the fact that, although the council's operations are unique, they are not beyond the pale of precedent.

The problem posed by the council's procedures might be characterized as one of consistency. Treating likes alike is thought to be a fundamental underpinning of fairness, and fairness is of course an important component of a legitimate government program. ${ }^{251}$ But FSOC's designation system arguably treats similar firms (and competing regulators) differently.

Moreover, a traditional response to claims of arbitrariness in administrative law turns not just on the reasonableness of a particular decision, but also on the process used to make decisions. ${ }^{252}$ The council is not unfamiliar with notice, comment, or judicial review. ${ }^{253}$ But when it has used notice and comment in spelling out its approach to designation, it has preserved for itself a quantum of discretion in applying the designation factors to address new and different risks, as we have seen. ${ }^{254}$ It has also rejected invitations from industry to perform a quantitative cost-benefit analysis of its rules. ${ }^{255}$ It offers its explanations in a writing, rather than a spreadsheet.

251 But see Kenneth I. Winston, On Treating Like Cases Alike, 62 Cal L Rev 1, 5 (1974) (arguing that the treat-likes-alike principle is "incomplete").

252 Ronald J. Krotoszynski Jr, "History Belongs to the Winners": The BazelonLeventhal Debate and the Continuing Relevance of the Process /Substance Dichotomy in Judicial Review of Agency Action, 58 Admin L Rev 995, 998 (2006) ("An agency that ignores process values invites presumably unwanted judicial scrutiny. Conversely, an agency that scrupulously observes fundamentally fair processes will receive a higher measure of deference from a reviewing court."). See also Loren A. Smith, Judicialization: The Twilight of Administrative Law, 1985 Duke L J 427, 429 ("We have come to believe that public hearings, public disclosure of all documents relevant to a given issue, and trialtype methodologies for testing ideas will lead to 'better' social and economic policies by government decisionmakers having power over large sections of the economic and social life of the nation.").

253 See Part II.A.

254 See Part II.A.

255 There are a number of scholars who have called for quantitative cost-benefit analysis to inform as many rules as possible. See, for example, Eric A. Posner and E. Glen Weyl, The Case for Cost-Benefit Analysis of Financial Regulations, 36 Reg 30, 32-34 (Winter 2013-2014); Cass R. Sunstein, Is Cost-Benefit Analysis for Everyone?, 53 Admin L Rev 299, 303-09 (2001) (favoring, in large part, cost-benefit analysis, but observing that costbenefit analyses have several drawbacks); Richard L. Revesz and Michael A. Livermore, Retaking Rationality: How Cost-Benefit Analysis Can Better Protect the Environment and Our Health 9-10 (Oxford 2008). But there are many who disagree. See, for example, Coates, 124 Yale L J at 997-98 (cited in note 174) (arguing that the "capacity of anyoneincluding financial regulatory agencies, OIRA, academic researchers, CBA/FR proponents, litigators, and courts - to conduct quantified CBA/FR with any real precision or confidence does not exist"); Lisa Heinzerling, Regulatory Costs of Mythic Proportions, 107 Yale L J 1981, 2042 (1998) (decrying the "[p]erils of [p]recision"). 
We are untroubled by this regulatory approach. Any enforcement scheme depends on singling out some unlucky wrongdoers from a larger pool of candidates. ${ }^{266}$ As Judge Richard Posner has observed, our legal system has never required laws to be enforced "with Prussian thoroughness as the price of being allowed to enforce them at all."257 The Supreme Court has emphasized that an "agency generally cannot act against each technical violation of the statute it is charged with enforcing." ${ }^{268}$

Given these modest constraints, prioritizing administrative action against high-profile targets who meet the statutory criteria, and who might deter others from illegality, might be considered good regulatory practice. ${ }^{259}$ Professors Daniel Bailis and Robert MacCoun have noted that "high-profile enforcement efforts create an exaggerated perception of legal risks, promoting compliance with the law," and in our view this is an advantage..$^{260}$ Regulators always need to choose who they enforce against, and they often-entirely appropriately-prioritize high-profile defendants, in an effort to deter others who might find themselves in their shoes. ${ }^{261}$

Even the idea of regulation by threat is not new-social scientists have written about "regulatory threat," 262 and it is particularly well known to those who study financial regulation, for

256 The Treasury Department has indicated that its tax enforcement scheme looks in particular for high-profile tax avoiders, and does not purport to prosecute every tax cheat. Tax threats themselves are traditional tools in the regulatory arsenal. See Internal Revenue Service, Internal Revenue Manual, Policy Statement § 1.2.20.1.1 (June 29, 2004), archived at http://perma.cc/N3JF-JSZA ("Penalties are used to enhance voluntary compliance.").

257 Hameetman $v$ City of Chicago, 776 F2d 636, 641 (7th Cir 1985). See also Oyler $v$ Boles, 368 US 448, 456 (1962) ("'T] he conscious exercise of some selectivity in enforcement is not in itself a federal constitutional violation.").

258 Heckler $v$ Chaney, 470 US 821, 831 (1985).

259 One SEC commissioner observed that "[h]igh profile cases generate significant returns on the SEC's enforcement dollars by sending very public messages of deterrence." Jacquelyn Lumb, Casey Reviews Current Enforcement Challenges (SEC Today, Sept 11, 2007) (available on Westlaw at 2007 WL 9384944).

260 Daniel S. Bailis and Robert J. MacCoun, Estimating Liability Risks with the Media as Your Guide, 80 Judicature 64, 65 (1996).

261 Sometimes lawmakers threaten to tax behavior that they want less of, an idea associated with the economist Arthur Pigou, who suggested that "[i]t is, however, possible for the State . . to remove the divergence ... by 'extraordinary encouragements' or 'extraordinary restraints." A.C. Pigou, The Economics of Welfare 192 (Macmillan 4th ed 1938). For a discussion, see Eric W. Orts, Reflexive Environmental Law, $89 \mathrm{Nw}$ U L Rev 1227,1242 (1995) ("'A] modern Pigouvian approach assesses taxes or charges to activities that are environmentally harmful.").

262 Victor Stango, Strategic Responses to Regulatory Threat in the Credit Card Market, 46 J L \& Econ 427, 430 (2003). See also Guy Halfteck, Legislative Threats, 61 Stan L Rev 
whom warnings and even threats to the banking industry are part and parcel of how informal financial regulation gets done. ${ }^{263}$ More generally, Professor Wu has categorized a wide array of informal agency action as, essentially, "agency threat." 264 Professor Lars Noah has dissected "administrative arm-twisting," and he adjudged it to be an acceptable form of regulation.265 Part of what has animated the campaign against FSOC is thus a discomfort with a form of regulation that in many ways is quite traditional.

Moreover, the council's refusal to provide industry-segment safe harbors-an announcement that, say, asset management firms could never grow too big to fail-looks entirely consistent with the administrative practice of other law enforcement agencies that must supervise an entire industry, and so are accordingly unwilling to issue free passes to parts of it. ${ }^{266}$

Every agency will regulate to some degree by rule and in other ways by what it chooses to prioritize in enforcement. When

629,638 (2008) ("[C]ompliance with legislative threats is, in essence, an implicit and informal political bargain in which the legislator barters the non-use of legislative power with respect to a particular issue in return for a firm's (or an industry's) commitment to change its conduct.").

263 As Professor Saule T. Omarova has observed, "[A] credible threat of targeted government intervention, such as a direct ban on complex financial products, and the creation of functional substitutes for public-interest-group monitoring of the industry's performance may serve as important external checks on the industry." Saule T. Omarova, Wall Street as Community of Fate: Toward Financial Industry Self-Regulation, $159 \mathrm{U}$ Pa L Rev 411,475 (2011).

264 See generally Wu, 60 Duke L J 1841 (cited in note 24). Wu argues that informal agency actions are "most useful ... when the agency faces a problem in an environment in which facts are highly unclear and evolving. Examples include periods surrounding a newly invented technology or business model . . . Conversely, in mature, settled industries, use of informal procedures is much harder to justify." Id at 1842.

265 Lars Noah, Administrative Arm-Twisting in the Shadow of Congressional Delegations of Authority, 1997 Wis L Rev 873, 875.

266 FSOC has retained its flexibility here, noting that it "believes financial stability concerns may arise from liquidity and redemption risks in pooled investment vehicles, particularly where investor redemption rights and underlying asset liquidity may not match." Statement on Review of Asset Management Products and Activities (FSOC, Apr 18, 2016), archived at http://perma.cc/558Z-6D5N. 
lawbreaking is difficult to catch-as in antitrust 267 and tax evasion ${ }^{268}$ - the discretion to single out some in an effort to deter others might be defensible. When the downside risk is high, as with nuclear power plants or hygiene in meat processing plants, regulatory discretion might be welcome. Some observers would include terrorism and enemy-state financing in this category of risks, and perhaps unsurprisingly, our terrorismfinancing regime works through a process of designation and deterrence. ${ }^{269}$ And when the right approach for policymakers is uncertain, a zone of discretion is appropriate-this might explain why diplomacy and monetary policy have not been subjected to the discipline of the APA. ${ }^{270}$

As for the conventions for important administrative actions, the traditions of ex ante precision and ex post cost-benefit analysis are not a sine qua non of good regulation. Some of the most effective regulations ever passed-such as the rule banning the widespread sale of leaded gasoline ${ }^{271}$ or the rules requiring the disclosure of information that a reasonable investor would want to know before deciding whether to buy or sell to all market participants, rather than a select few ${ }^{272}$-lacked these characteristics. The council's approach is no outlier when compared to these successful regimes.

267 At least, this has been the history in antitrust enforcement. See, for example, B. Zorina Khan, Federal Antitrust Agencies and Public Policy toward Antitrust and Intellectual Property, 9 Cornell J L \& Pub Pol 133, 141 (1999) (noting that, in a sample of cases brought between the 1970 s and the present, "the correspondence in the identity of antitrust firms with a list of firms that are household names suggests the possibility that antitrust authorities are pursuing a 'big bang' policy, where limited resources are allocated towards the prosecution of cases that are most likely to generate attention").

268 The idea is explicitly one of deterrence: "[H]igh-profile cases emphasize the abilities and enforcement power of the IRS's criminal investigators, sending the message that "If the IRS can get these untouchables, certainly they can get me." Stephen W. Mazza, Taxpayer Privacy and Tax Compliance, 51 U Kan L Rev 1065, 1126 (2003). See also Kelly Phillips Erb, IRS Investigations, Prosecutions for Tax Crimes Up in 2013 (Fortune, Feb 26, 2014), archived at http://perma.cc/LK34-LWGM (noting the increase in high-profile criminal tax prosecutions of, among others, the mayor of Detroit).

269 See note 35 and accompanying text.

270 See 5 USC $\S 553$ (exempting foreign and military affairs from APA rulemaking requirements). See also David Zaring, Law and Custom on the Federal Open Market Committee, 78.3 L \& Contemp Probs 157, 158, 171-76 (2015) (describing the administrative law of the committee and observing that it is not constrained by the APA).

271 Craig N. Oren, When Must EPA Set Ambient Air Quality Standards? Looking Back at NRDC v. Train, 30 UCLA J Envir L \& Pol 157, 181 (2012) ("[T]he leaded gasoline rules were the chief cause of a ninety-nine percent reduction in lead emissions to the air from 1970 to 2005 , clearly a record of success.").

27217 CFR Part 243. See also Laura S. Unger, Special Study: Regulation Fair Disclosure Revisited *1 (SEC, Dec 2001), archived at http://perma.cc/SNH7-7TAT (reporting that 


\section{B. The Substantive Constraints on the Council's Authority}

Although regulation by threat can therefore be a legitimate tool in some circumstances, there is little doubt that it must be constrained to prevent abuses of power and excessive uncertainty. Although FSOC does retain substantial discretion to designate nonbanks, that discretion is subject to important substantive constraints.

Some of these restrictions are embedded within Dodd-Frank or FSOC's implementing rules, and discussed at length in Part II.A. These include the requirement that 85 percent of a firm's activities must be "financial in nature" for it to be designated and that the designation decision must include consideration of ten relevant factors. ${ }^{273}$ Even more importantly, they include the panoply of Stage 1 quantitative triggers including, perhaps most importantly, the $\$ 50$ billion asset threshold. ${ }^{274}$ The vast majority of nonbanks do not pass these Stage 1 triggers, and can confidently determine this for themselves. ${ }^{275}$

But the substantive limits on FSOC's designation authority extend beyond these straightforward examples. First, FSOC's three-stage procedure for considering firms for designation limits its capacity to designate nonbank financial firms that were previously examined in Stages 2 or 3 and deemed not to pose a systemic threat. Firms that pass Stage 1 of the FSOC process but were ultimately not designated are aware of these facts. ${ }^{276}$ As a result, these firms can generally rest assured that they will not be designated in the future if they do not substantially alter their balance sheet and activities. Were FSOC to reverse course on a prior determination without such a shift in the firm's risk profile, a court would almost certainly set aside this action as arbitrary and capricious.

Second, FSOC's discretion regarding the substantive criteria for identifying nonbank SIFIs will naturally diminish over time

the rule was proposed in January 2000 and adopted in August 2000; notably, this report reviewing the rule one year after implementation contains no cost-benefit analysis). For an overview, see Donald C. Langevoort, Taming the Animal Spirits of the Stock Markets: A Behavioral Approach to Securities Regulation, 97 Nw U L Rev 135, 163 (2002).

273 See notes 117-20 and accompanying text.

274 See Part II.A.1.

275 Although FSOC retained its right to consider a firm for designation if it did not pass Stage 1, it would face a substantially heightened burden if it in fact acted against such a firm. See 77 Fed Reg at 21642-45 (cited in note 123).

276 See Part II.A. 
as more precedents and explanations for those precedents develop. FSOC has taken a rather explicit wait-and-see approach about designating the largest asset managers-such as BlackRock-as SIFIs, in part because the SEC's rules are still in development. 277 The same uncertainty no doubt applies in the context of the GSEs, as FSOC has to date refrained from designating any of the GSEs because of the uncertainty regarding the regulatory environment that these firms face. ${ }^{278}$ But in both instances, this uncertainty is likely to be a temporary result of the fact that core elements of the primary regulatory regime for these entities are still under development. Once essential questions are resolved about how to regulate these types of firms and the activities in which they engage, then the nonbanks that populate these industries will have substantially more certainty about their status as nonbank SIFIs.

None of this supports a narrative that the council is a roving commission of unconstrained apparatchiks. ${ }^{279}$ The council has retained a degree of discretion, but when it comes to assessing the arbitrariness of agency actions, the council's discretion, it must be conceded, lies in narrow and cabined areas. Moreover, it is worth underscoring that the council's remit to impose financial safeguards on a broad array of firms is necessary to the project of avoiding systemic risk. We now know that the financial crisis was exacerbated, and in some ways may have been precipitated, by the risky activities of an unpredictable array of different nonbank financial actors. ${ }^{280}$ The only way to regulate finance-with its ever-lower barriers to entry and ever-larger number of institutions interested in providing it-is with flexibility, and with credible warnings. The financial sector is not just full of knowns, or known unknowns, but also has its share of unknown unknowns, at least from the perspective of the regulator. ${ }^{281}$ The liquidity of

277 See Financial Stability Oversight Council, Update on Review of Asset Management Products and Activities *2-4 (Apr 18, 2016), archived at http://perma.cc/EP3E-PT3R.

278 See Financial Stability Oversight Council, 2016 Annual Report *16 (June 21, 2016), archived at http://perma.cc/8B87-SRY5 (recommending housing finance reform).

279 Unlike the National Industrial Recovery Act, which Justice Benjamin Cardozo famously describe as "delegation running riot." A.L.A. Schechter Poultry Corp v United States, 295 US 495, 553 (1935) (Cardozo concurring).

280 See Part I.A.

281 "[T] $]$ here are known unknowns; that is to say we know there are some things we do not know. But there are also unknown unknowns - the ones we don't know we don't know." US Department of Defense, DoD News Briefing-Secretary Rumsfeld and Gen. Myers (Feb 12, 2002), archived at http://perma.cc/AL4K-ZLRX. 
the American capital markets requires a vast number of participants offering a vast array of products. Perfectly identifying which of these participants are the risky ones in advance has never been possible in the past, and is even more unlikely today.

\section{The Procedural Curbs on the Council's Discretion}

The council's adoption of regulation by threat is further bolstered by the novel procedural protections incorporated into the FSOC scheme. It has voting requirements, a seat at the table for different kinds of regulators, including, almost uniquely, state regulators, an international check not shared by many federal agencies, along with, of course, some standard procedural protections. These checks help offset any rule-of-law concerns associated with the council's retention of flexibility in the designation process as well as its refusal to assess quantified costs and benefits in connection with individual designation decisions; we review them here in turn.

The structure of the council, which includes a diverse array of agency heads, helps. Each of the heads of the nine federal agencies on the council, along with an independent member with insurance expertise, must vote before any designation is made. A designation is finalized only with an affirmative vote from seven of these FSOC members, which must include the secretary of the treasury. ${ }^{282}$ With the exception of the independent member, all of these FSOC members are financial regulators, but they regulate very different aspects of the financial system. The Fed, Office of the Comptroller of the Currency, NCUA, and FDIC regulate banks or bank-like institutions. ${ }^{283}$ The SEC and CFTC supervise the capital markets. ${ }^{284}$ The FHFA regulates the government sponsored mortgage securitization giants. ${ }^{285}$ The director of the Consumer Financial Protection Bureau is charged with protecting the

282 Dodd-Frank Act $\S 113(\mathrm{a})(1), 124$ Stat at 1398, 12 USC $\S 5323(\mathrm{a})(1)$.

283 Oren Bar-Gill, The Law, Economics and Psychology of Subprime Mortgage Contracts, 94 Cornell L Rev 1073, 1094 (2009) ("Federal banking agencies-the Federal Reserve Board (FRB), the Office of the Comptroller of the Currency (OCC), . . the Federal Deposit Insurance Corporation (FDIC), and the National Credit Union Administration (NCUA) - regulate depository institutions.").

284 See Securities Exchange Act of 1934, Pub L No 73-291, 48 Stat 881, codified as amended at 15 USC $\S 78 \mathrm{a}$ et seq; Commodities Futures Trading Commission Act of 1974, Pub L No 93-463, 88 Stat 1389, codified as amended in various sections of Title 7 .

285 Housing and Economic Recovery Act of $2008 \S 1311(\mathrm{~b})$, Pub L No 110-289, 122 Stat 2654, 2661-62, codified at 12 USC § 4511(b). 
interests of consumers. ${ }^{286}$ And the secretary of the treasury is a political appointee with a vast array of diverse responsibilities. ${ }^{287}$

It is in many ways a "team of rivals," comprising agencies that have struggled against one another for turf, and in some cases, for budgets. ${ }^{288}$ The SEC and CFTC have been at loggerheads since their founding. ${ }^{289}$ Banks may choose their regulator by choosing who issues their bank charter; moreover, they can switch charters, and regulators, as they see fit, creating a competition of sorts between the agencies that bolster their budgets from fees from the number of banks they supervise. ${ }^{290}$

Few of these agencies have any reason to defer to a decision allocating supervision to the Fed. In fact, FSOC is in this way at least a partial example of a regulatory contrarian enterprise-a regulatory process that includes diverse opinions and even devil's advocates in an effort to provide checks on regulation before matters come to the courts. ${ }^{291}$

There are other reasons to believe that the way the council practices administrative law is, if different, not wrong. The council has essentially no budget and almost no employees, which renders it unlikely to be moved by the prospect of regulatory turfbuilding. ${ }^{292}$ It does not even have its own office building; its staff is housed in the Treasury Department. ${ }^{293}$ Nor does the council supervise the firms that it designates - that job is delegated to the Fed. Its decision to require regulation therefore does not create a regulatory program of its own that it could grow-one of the standard stories told about regulatory waste involves this sort of struggle for size, and there is no reason to believe that the council

286 See Dodd-Frank Act $\S \S 1011-12,124$ Stat at 1964-66, 12 USC $\S \S 5491-92$.

28731 USC $\S \S 301(\mathrm{~b}), 321$.

288 For a famous use of the term, see generally Doris Kearns Goodwin, Team of Rivals: The Political Genius of Abraham Lincoln (Simon \& Schuster 2005).

289 See, for example, John Manley, U.S. Market Regulators in Bid to End Turf War (Reuters, Sept 2, 2009), archived at http://perma.cc/BF89-VH26.

290 See Dain C. Donelson and David Zaring, Requiem for a Regulator: The Office of Thrift Supervision's Performance during the Financial Crisis, 89 NC L Rev 1777, 1781 (2011); Marcelo Rezende, The Effects of Bank Charter Switching on Supervisory Ratings *3 (Federal Reserve Board, Finance and Economics Discussion Series 2014-20, Mar 5, 2014), archived at http://perma.cc/UY5F-6ZDT.

291 Brett McDonnell and Daniel Schwarcz, Regulatory Contrarians, 89 NC L Rev 1629, 1649 (2011).

292 See Eva Becker, Knowledge Capture in Financial Regulation: Data-, Informationand Knowledge-Asymmetries in the U.S. Financial Crisis 108 (Springer 2016).

293 Allen, 76 Ohio St L J at 1114-15 (cited in note 102) (noting that the council has a dedicated staff of twenty-five employees and a budget of less than $\$ 10$ million). 
would engage in it. ${ }^{294}$ FSOC lacks this famous incentive to regulate, in other words, because there is no advantage to the council in doing so.

Another source of FSOC's process legitimacy stems from the political accountability of its member agencies. The chair of the council is the secretary of the treasury, a political appointee removable from his job at will, and, as such, is accountable to the president. Moreover, the secretary of the treasury has a veto right against designation. ${ }^{295}$ It is a role that underscores Professor Gillian Metzger's argument that "[t]he creation of the FSOC can be seen as part of an effort to inject more political accountability into financial-system oversight," rather than less. ${ }^{296}$

Most of the other members of the council are independent regulators. Although they will tend to be members of the same political party (whichever party controls the White House), they generally are not subject to presidential oversight. By putting the heads of those agencies on the council, Dodd-Frank has created a council full of presidentially appointed, Senate-confirmed voting members. This is not a particularly unique facet of agency leadership, but by making each of the financial regulators with voting rights subject to senate confirmation, which requires the approval of not just the banking committee, but other committees that oversee other regulatory members, such as the agriculture and commerce committees, the legislative stakeholders in the council's enterprise are larger than they are in the case of other agencies.

It is accordingly no surprise that designations do not look like an obscurantist technocratic exercise. In the case of MetLife, the council looked at practicalities as well as at the risks posed by MetLife. It observed, for example, that MetLife's current state regulators "have never been tested by the material financial distress of an insurance company of the size, scope, and complexity of MetLife's insurance subsidiaries." 297 When rescinding the designation of GE Capital, the council made both technocratic and

294 It is true that the council must review designated firms on an annual basis to see if they are still systemically risky, but it is hard to see how this builds turf for the council, as it relies on staff from its member agencies to conduct these reviews. See Nonbank Designations-FAQ (cited in note 121).

295 See text accompanying note 109.

296 Gillian E. Metzger, Through the Looking Glass to a Shared Reflection: The Evolving Relationship between Administrative Law and Financial Regulation, 78.3 L \& Contemp Probs 129, 146 (2015).

297 MetLife Designation at *27 (cited in note 147). 
practical findings. It observed that "GE Capital has decreased its total assets by over 50 percent, shifted away from short-term funding, and reduced its interconnectedness with large financial institutions," terms of regulatory art.298 But it observed in practical terms that these changes also meant that it was no longer acting like a bank: "[T] he company no longer owns any U.S. depository institutions and does not provide financing to consumers or small business customers in the United States."299

Yet another source of process legitimacy stems from the unique diversity of the council's decision-making process. State insurance, securities, and banking commissioners play a role in designation decisions-they are each nonvoting members, along with the heads of the Federal Insurance Office and the Office of Financial Research. ${ }^{300}$ This state representation adds an alternative perspective to the enterprise, a perspective that other federal agencies cannot match; none of them include state representatives in the same way. ${ }^{301}$ There are many regulatory projects that are enterprises in which the states and the federal government must cooperate - the Environmental Protection Agency relies on the states to come up with local plans to deal with water and air pollution, the Affordable Care Act ${ }^{302}$ relies in part on state-run exchanges, and so on-but these relationships do not put state regulators at the leadership table of a federal enterprise. By including states on the council, FSOC is unique.

As Metzger has observed, it is a particular difference for finance; the "incorporation of state regulators is a departure from the dual banking system that long dominated the nation." ${ }^{303}$ Instead, FSOC looks more like a coordination exercise of independent and politically accountable regulators, with limited powers to force each other to act or vote in a particular way.

Finally, the council's designation process is part of a global effort to identify systemically risky firms and do something about

298 Rescission of GE Determination at *2 (cited in note 17).

299 Id.

300 Who Is on the Council? (FSOC, May 10, 2017), archived at http://perma.cc/BV52-225L.

301 State officials are not placed in leadership roles in federal programs, though state officials often enjoy powers delegated to them by Congress, a fact that has worried some scholars who take the nondelegation doctrine particularly seriously. See, for example, Thomas W. Merrill, Rethinking Article I, Section 1: From Nondelegation to Exclusive Delegation, 104 Colum L Rev 2097, 2167 n 267 (2004) ("Delegations to state entities may be permissible in circumstances in which delegations to private entities would not be.").

302 Patient Protection and Affordable Care Act, Pub L No 111-148, 124 Stat 119 (2010).

303 Metzger, 78.3 Law \& Contemp Probs at 150 (cited in note 296). 
them. Others have criticized this international constraint as one that removes power from the council; in our view, it acts as an additional, and novel, constraint on the council's discretion. ${ }^{304}$

If the FSB, an international body of financial regulators, to which America sends representatives, but at which the council has no formal role, believes that an American financial institution is systemically risky, it can make its own designation. ${ }^{305}$ The FSB has promulgated a list of so-called G-SIBs, or globally systemically important banks, ${ }^{306}$ and, intriguingly, G-SIIs, or globally systemically important insurers, of whom there are currently nine, three of which are the American insurers MetLife, Prudential, and AIG. ${ }^{307}$

This independent designation process limits the ability of the council to let "national champions" become systemically risky in an effort to gain global market share or represent American interests. ${ }^{308}$ Moreover, it is consistent with the purpose of international economic law, which might be broadly characterized as seeking to reduce regulatory barriers and facilitate trade among them. The World Trade Organization (WTO), for example, has as one of its "pillars" a commitment to "national treatment," or treating foreign and domestic firms the same way. ${ }^{309}$

To be sure, some have criticized the council for hewing too closely to the designations of the FSB. ${ }^{310}$ Two of the four designations made by the council were first made by the international entity. ${ }^{311}$ But one would expect government bodies on the lookout

304 See Part III.

305 The FSB's methodology for identifying systemically significant insurers is described in notes $117,165,173$ and accompanying text.

306 See generally Financial Stability Board, 2015 Update of List of Global Systemically Important Banks (G-SIBs) (Nov 3, 2015), archived at http://perma.cc/C9QV-XZXA.

307 See Financial Stability Board, 2015 Update of List of Global Systematically Important Insurers (G-SIIs) *3 (Nov 3, 2015), archived at http://perma.cc/X9RB-R3JY.

308 Designation by the FSB arguably has no independent legal effect, but the members of the board, which include American and foreign regulators, have committed themselves to implement policies formulated by the board. G.A. Walker, International Financial Instability and the Financial Stability Board, 47 Intl Law 1, 29-30 (2013) ("[T] he legal effectiveness of any of the FSB's work is expressly excluded ... with implementation being dealt with through member commitment."). Designation by the board as a global systemically important insurer would mean that board regulators outside of the United States would be expected to subject American firms doing business to heightened supervision, especially if FSOC's designation decision was delayed. See id at 41 (describing the interaction between the FSB's global priorities and institutions like FSOC).

309 See Raj Bhala, International Trade Law Handbook: Theory and Practice 423-98

(Lexis $2 \mathrm{~d}$ ed 2001) (describing national treatment as one of four pillars of the WTO).

310 See note 4 and accompanying text.

311 See Zaring, 52 Va J Intl L at 700-01 (cited in note 39 ). 
for systemic risk to evaluate risk in similar ways; the correlation between international designations and council designations is not exact, and, of course, the council, through its members, has a voice in the international process itself.

\section{Implications for Policy}

Ever since it first began to do business, the council has been on the receiving end of criticism from the financial industry. Congress has indicated some receptivity to these concerns. ${ }^{312}$ The council has been threatened with legislation that would undo much of its useful work in making the regulatory system safer. This final Section contributes to the policy debate by explaining why the reforms proposed for the council are unlikely to contribute to the success of its mission once the way it has been constructed is fully understood. Those more interested in the council as an example of regulation by threat may be less interested in our proposals here. It is the part of the Article for those most interested in right-sizing the council. Our bottom line is that none of the reforms that have been proposed for the council look worth pursuing, even if other types of reforms might well be sensible.

Some recent proposals would entirely eliminate FSOC's authority to designate nonbanks as systemically significant. ${ }^{313}$ There have been jurisdictional proposals. The Senate has considered increasing the asset threshold for automatic designation as a systemically important financial institution from $\$ 50$ billion to $\$ 500$ billion. . $^{314}$

There have been a variety of procedural reforms proposed. Legislation introduced by the chair of the Senate Banking Committee would permit all of the members of various agencies that are part of the council to attend meetings (currently, it is only the chair who may attend), along with members of congressional oversight committees. ${ }^{315}$ Also introduced have been procedural reforms for nonbank designation determinations. These would require more notice and comment about designation standards and

312 See text accompanying notes 314-20.

313 See generally The Financial CHOICE Act (cited in note 10).

314 Victoria McGrane and Ryan Tracy, Sen. Shelby to Unveil Legislation Heightening Fed Security (Wall St J, May 11, 2015), online at http:/www.wsj.com/articles/sen-shelby -to-unveil-legislation-heightening-fed-scrutiny-1431393248 (visited Aug 26, 2017) (Perma archive unavailable).

315 Id. 
more hearing rights. ${ }^{316}$ Targeted institutions would have additional opportunities to meet and confer with the council before designation. ${ }^{317}$ The council would also have to give a targeted firm an opportunity to file a remedial plan addressing the concerns raised by the regulators. ${ }^{318}$ That plan could be paired with action by the primary regulator of the targeted firm..$^{319}$

Finally, the international constraints on the council have been criticized. Some proposals would preclude the council and its members from operating internationally without first going through domestic notice and comment. ${ }^{320}$

Our objections to the most extreme of these proposals-which would entirely eliminate FSOC's designation authority-should be clear based on the Article's arguments to this point. But we also believe that many-though perhaps not all -of the more "moderate" reforms of the council's designation process are also misguided. The net effect of these rules would make it more difficult for the council to designate nonbank firms as systemically significant. They would represent an effort to tie the hands of the council in advance of future designations. They also would make those designations easier to challenge in court-more rulemaking and procedural requirements risk ossifying the council's processes and create tripwires that aggressive courts could police harshly. ${ }^{321}$

Several of the proposed reforms-such as the attempt to exempt from designation companies with under $\$ 500$ billion in assets-would further undermine FSOC's designation process by explicitly limiting FSOC's discretion to seek out new forms of risk in the financial system. ${ }^{322}$ To be sure, we support the council's current presumptive Stage 1 safe harbor, which partially incorporates a $\$ 50$ billion asset size measure. But this support is premised on the fact that the Stage 1 quantitative thresholds clearly err on the side of overinclusiveness, thus providing certainty to firms that are almost certainly too small to be systemically significant while preserving FSOC discretion for firms that are

316 Id.

317 See id.

318 See McGrane and Tracy, Sen. Shelby to Unveil Legislation (cited in note 314).

319 See id.

320 Legislation Addressing International Insurance Standards Introduced in U.S. Congress (Mayer Brown, Aug 7, 2015), archived at http://perma.cc/LHU2-5HU3.

321 For some of these concerns, see Thomas O. McGarity, Some Thoughts on "Deossifying" the Rulemaking Process, 41 Duke L J 1385, 1403-07 (1992).

322 See Part III.A. 
plausibly close to the borderline of systemic importance based on inherently imperfect metrics such as asset size. By contrast, increasing the threshold to match the actual asset levels of firms that have been designated to date would directly undermine this approach, offering financial firms with under $\$ 500$ billion in assets blank checks to take on risky activity, and increasing the risk of a crisis-which, if it occurred, might impel the government to somehow arrange for a bailout of these firms.

Other proposed reforms would undermine FSOC's engagement with international bodies. International efforts, after all, can constrain domestic action, as we have seen. Much of what goes on at international institutions is a negotiation, and American representatives must have the ability to participate in those negotiations. Requirements that proposed international deals on other aspects of what the council does be published in the Federal Register is a needless layering on of notice and comment on top of notice and comment. Domestic regulators must and do bring international agreements back home for notice and comment before implementing them-and the council has put plenty of rules through the notice-and-comment process. ${ }^{323}$ And we have seen plenty of examples of cases in which domestic notice and comment regularly changes the content of international agreements - the Fed's two-track implementation of the second version of the Basel capital accords is an example. ${ }^{324}$ Few negotiation experts advise people to regularly make public disclosures of their goals and how they think the negotiations are going. ${ }^{325}$

Nor does it make sense to impose nakedly burdensome opengovernment requirements on the council or its members; one of the useful lessons of the efforts to change the council's governing legislation is that they include a very large number of transparency measures that are obviously designed to slow regulation, rather than improve it. It is a corrective to those who believe that more sunshine is always better. ${ }^{326}$

323 See David Zaring, Sovereignty Mismatch and the New Administrative Law, 91 Wash U L Rev 59, 80-81 (2013). See also generally Financial Stability Oversight Council: Significant Documents (Federal Register), archived at http://perma.cc/69FW-6DXY.

324 See Zaring, 91 Wash U L Rev at 80-85 (cited in note 323).

325 Kevin R. Schock, Book Review, Getting to Yes: Remembering Roger Fisher, 5 Yearbook Arb \& Mediation 422, 434 (2013) (describing the limited reasons why a negotiator might want to disclose her bottom line).

326 See The Ayes Have It (The Economist, Apr 28, 2012), archived at http://perma.cc/QMV3-VXDZ (discussing a German political party with a transparency "fetish" that, its rivals claim, has made its "elected representatives ... useless"). 
Public-observer access for stakeholders to international working groups and committee meetings also limits the ability of negotiators to in fact negotiate-it risks creating the problems for international regulators that the well-intentioned Government in the Sunshine Act ${ }^{327}$ has created for domestic regulators like the Securities and Exchange Commission, whose commissioners cannot meet privately to hash out their differences. ${ }^{328}$ If, for example, every state insurance commissioner could attend a council meeting when insurance companies are being considered by designation, they would vastly outnumber anyone else in the room. It is difficult to see how that adds value, given that a state insurance commissioner already attends meetings of the council as a nonvoting member. ${ }^{329}$

We therefore enter the policy debates by recommending against the legislative proposals designed to reign the council in, because reigning is not what the council needs-it needs discretion. We are not unblinking apologists for the regulatory state. Although we defend the council's discretion in this Article, and the way it has exercised that discretion, we do not proffer it as the best of all possible government institutions. The fact that it is a committee of regulators obviously reflects compromises with the path-dependent realities of financial regulation as it existed before Dodd-Frank, rather than a perfect reimagining of those agencies. ${ }^{330}$

As such, we do indeed think a number of reforms to FSOC could be sensible. For instance, although there is something to be said for the chairmanship of the secretary of the treasury-it makes the council more politically accountable—the secretary's role, as a politically appointed actor overseeing a technocratic exercise, does not come without costs. ${ }^{331}$

327 Pub L No 94-409, 90 Stat 1241 (1976), codified in various sections of Title 5.

$328 \mathrm{Jim}$ Rossi, Participation Run Amok: The Costs of Mass Participation for Deliberative Agency Decisionmaking, 92 Nw U L Rev 173, 230 (1997) (“The Sunshine Act's requirements impair the ability of agency members to deliberate, adversely affect the establishment of agency agendas, and promote inefficient practices within agencies.").

329 See notes 300-03 and accompanying text (describing the role and importance of state regulators).

330 In 2009, the Treasury Department released a report calling for a total reorganization of the regulatory field. See generally US Department of the Treasury, Financial Regulatory Reform-a New Foundation: Rebuilding Financial Supervision and Regulation (June 17, 2009), archived at http://perma.cc/QR95-HNT2. For a discussion, see generally Cunningham and Zaring, 78 Geo Wash L Rev 39 (cited in note 167).

331 As a former comptroller of the currency recently observed, "In prior decades, Congress, as a matter of public policy, had been deeply wary of giving this kind of authority to 
Moreover, all of the other voting council members are the chairs of their commissions, which means that they have all been appointed by the sitting president and will all be members of his party. We could imagine a council that made room for different sorts of voices, perhaps by including voting roles for state officials, or a somewhat broader composition, without making every member of every financial regulatory board a voting member of the council. Votes that include different political perspectives may be more likely to create better, or at least more broadly palatable, policies, but the council as currently constituted does not offer this sort of diversity. ${ }^{332}$ These changes, however, would affect the structure of the council and not its decision-making process or its discretion, both of which we defend.

\section{CONCLUSION}

The financial crisis was exacerbated by the collapse of both banks and nonbanks. Insurance firms and money market funds were particularly unstable and contributed at least as much to the crisis as did problems at large deposit institutions like Citigroup and Bank of America. Congress could have created new regulators to supervise the prudential risks posed by some predefined subset of these nonbank institutions. Instead, it chose to authorize a group of existing regulators-the council-to pick out the riskiest of these institutions and to subject them to more intensive oversight. The point of this process was not only to supervise the most dangerous of the nonbanks, but to warn institutions like them that if they engaged in systemically risky activities, they could also be subjected to intensive oversight. We argue that this regulatory approach is both reasonable and natural.

It is hardly surprising that such regulation by threat scares nonbank financial firms, as well as their immediate supervisors.

a Treasury Secretary, a member of the President's Cabinet whose position is inherently political in nature." Eugene A. Ludwig, Assessment of Dodd-Frank Financial Regulatory Reform: Strengths, Challenges, and Opportunities for a Stronger Regulatory System, 29 Yale J Reg 181, 196 (2012). See also The Volcker Alliance, Reshaping the Financial Regulatory System: Long Delayed, Now Crucial *30 (2015), archived at http://perma.cc/28ZD -PST4 (proposing, among other things, that the secretary of treasury lose a vote on FSOC to reduce the politicization of the council's work).

332 The benefits of diverse groups of policymakers, after all, are behind the requirement that agency boards include members from different parties. Moreover, Professors Sunstein and Thomas J. Miles have argued that "there is more reason to trust the outcomes of mixed panels than the outcomes of unified panels" in administrative-law cases, whether at the agency or judicial level. Cass R. Sunstein and Thomas J. Miles, Depoliticizing Administrative Law, 58 Duke L J 2193, 2230 (2009). 
But sometimes the threat of oversight induces the right amount of caution. There is every reason to believe that a roughly appropriate amount of caution has been struck in the supervision of nonbanks today. Moreover, we think that this sort of regulation by threat could be a model for regulatory problems posed when information is limited, error is likely, and the costs of a mistake are high. In such contexts, regulation by threat is not only a reasonable choice, but it may well be good, and perhaps the best, policy. 


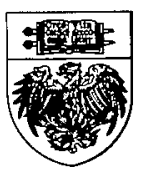

